\title{
Liquid-liquid phase separation and viscosity within secondary organic aerosol generated from diesel fuel vapors
}

\author{
Mijung Song ${ }^{1,2}$, Adrian M. Maclean ${ }^{2}$, Yuanzhou Huang ${ }^{2}$, Natalie R. Smith ${ }^{3}$, Sandra L. Blair ${ }^{3}$, Julia Laskin $^{4}$, \\ Alexander Laskin ${ }^{4}$, Wing-Sy Wong DeRieux ${ }^{3}$, Ying $\mathbf{L i}^{3}$, Manabu Shiraiwa ${ }^{3}$, Sergey A. Nizkorodov ${ }^{3}$, and \\ Allan K. Bertram ${ }^{2}$ \\ ${ }^{1}$ Department of Earth and Environmental Sciences, Chonbuk National University, Jeollabuk-do, 54896, Republic of Korea \\ ${ }^{2}$ Department of Chemistry, University of British Columbia, Vancouver, BC, V6T 1Z1, Canada \\ ${ }^{3}$ Department of Chemistry, University of California Irvine, Irvine, CA 92697, USA \\ ${ }^{4}$ Department of Chemistry, Purdue University, West Lafayette, IN 47907, USA
}

Correspondence: Allan K. Bertram (bertram@chem.ubc.ca)

Received: 17 April 2019 - Discussion started: 26 April 2019

Revised: 3 September 2019 - Accepted: 11 September 2019 - Published: 8 October 2019

\begin{abstract}
Information on liquid-liquid phase separation (LLPS) and viscosity (or diffusion) within secondary organic aerosol (SOA) is needed to improve predictions of particle size, mass, reactivity, and cloud nucleating properties in the atmosphere. Here we report on LLPS and viscosities within SOA generated by the photooxidation of diesel fuel vapors. Diesel fuel contains a wide range of volatile organic compounds, and SOA generated by the photooxidation of diesel fuel vapors may be a good proxy for SOA from anthropogenic emissions. In our experiments, LLPS occurred over the relative humidity $(\mathrm{RH})$ range of $\sim 70 \%$ to $\sim 100 \%$, resulting in an organic-rich outer phase and a water-rich inner phase. These results may have implications for predicting the cloud nucleating properties of anthropogenic SOA since the presence of an organic-rich outer phase at high-RH values can lower the supersaturation with respect to water required for cloud droplet formation. At $\leq 10 \% \mathrm{RH}$, the viscosity was $\geq 1 \times 10^{8} \mathrm{Pas}$, which corresponds to roughly the viscosity of tar pitch. At $38 \%-50 \% \mathrm{RH}$, the viscosity was in the range of $1 \times 10^{8}$ to $3 \times 10^{5} \mathrm{~Pa}$. These measured viscosities are consistent with predictions based on oxygen to carbon elemental ratio $(\mathrm{O}: \mathrm{C})$ and molar mass as well as predictions based on the number of carbon, hydrogen, and oxygen atoms. Based on the measured viscosities and the Stokes-Einstein relation, at $\leq 10 \% \mathrm{RH}$ diffusion coefficients of organics within diesel fuel SOA is $\leq 5.4 \times 10^{-17} \mathrm{~cm}^{2} \mathrm{~s}^{-1}$ and the mixing time of organics within $200 \mathrm{~nm}$ diesel fuel SOA particles $\left(\tau_{\text {mixing }}\right)$ is $50 \mathrm{~h}$. These small diffusion coefficients and large mixing
\end{abstract}

times may be important in laboratory experiments, where SOA is often generated and studied using low-RH conditions and on timescales of minutes to hours. At $38 \%-50 \% \mathrm{RH}$, the calculated organic diffusion coefficients are in the range of $5.4 \times 10^{-17}$ to $1.8 \times 10^{-13} \mathrm{~cm}^{2} \mathrm{~s}^{-1}$ and calculated $\tau_{\text {mixing }}$ values are in the range of $\sim 0.01 \mathrm{~h}$ to $\sim 50 \mathrm{~h}$. These values provide important constraints for the physicochemical properties of anthropogenic SOA.

\section{Introduction}

Volatile organic compounds (VOCs) are emitted into the atmosphere from both biogenic and anthropogenic sources (Kanakidou et al., 2005; Hallquist et al., 2009). These VOCs can be oxidized in the atmosphere, and the oxidized products can form secondary organic aerosol (SOA) (Hallquist et al., 2009; Ervens et al., 2011). SOA accounts for $20 \%-80 \%$ of the mass of atmospheric aerosol particles (Zhang et al., 2007; Jimenez et al., 2009) and plays an important role in climate, air quality, and public health (Kanakidou et al., 2005; Jang et al., 2006; Solomon, 2007; Baltensperger et al., 2008; Murray et al., 2010; Wang et al., 2012; Pöschl and Shiraiwa, 2015; Shiraiwa et al., 2017; Shrivastava et al., 2017a, b). Despite the importance of SOA, many of the physicochemical properties of SOA remain poorly understood.

One physicochemical property of SOA that remains insufficiently understood is liquid-liquid phase separation (LLPS) 
(Pankow, 2003; Marcolli and Krieger, 2006; Ciobanu et al., 2009; Bertram et al., 2011; Krieger et al., 2012; Song et al., 2012a; Zuend and Seinfeld, 2012; Veghte et al., 2013; You et al., 2014; O'Brien et al., 2015; Freedman, 2017). Very recent work has shown that SOA particles free of inorganic salts can undergo LLPS at a high relative humidity (RH) with implications for predicting the cloud nucleating properties of SOA (Petters et al., 2006; Hodas et al., 2016; Renbaum-Wolff et al., 2016; Ovadnevaite et al., 2017; Rastak et al., 2017; Song et al., 2017, 2018; Altaft et al., 2018; Liu et al., 2018; Davies et al., 2019; Ham et al., 2019). Several of these recent studies investigated SOA generated from a single VOC (e.g., $\alpha$-pinene or isoprene). However, in the atmosphere, SOA is formed from a complex mixture of VOCs (Odum et al., 1997; Schauer et al., 2002a, b; Vutukuru et al., 2006; Velasco et al., 2007; de Gouw et al., 2008; Velasco et al., 2009; Gentner et al., 2012; Liu et al., 2012; Hayes et al., 2015). Additional studies are needed to determine if SOA generated from a complex mixture of VOCs of atmospheric relevance can also undergo LLPS at high RH.

Another physicochemical property of SOA that remains poorly understood is viscosity. Viscosity together with the Stokes-Einstein equation can be used to predict diffusion rates of organics within SOA, which can critically impact a number of processes involving SOA. For example, diffusion of organics within SOA can impact particle size distributions (Shiraiwa et al., 2013a; Zaveri et al., 2014, 2018) and particle mass concentrations (Shiraiwa and Seinfeld, 2012; Ye et al., 2016; Yli-Juuti et al., 2017; Kim et al., 2019) in the atmosphere. Diffusion rates within SOA can also affect multiphase reactions (Shiraiwa et al., 2011; Zhou et al., 2013; Steimer et al., 2014; Houle et al., 2015; Li et al., 2018), the extent of long-range transport of pollutants (Zelenyuk et al., 2012; Zhou et al., 2013; Shrivastava et al., 2017b; Mu et al., 2018), ice nucleation (Murray et al., 2010; Wang et al., 2012; Wilson et al., 2012; Ladino et al., 2014; Schill et al., 2014; Knopf et al., 2018), and crystallinity of salts (Murray, 2008; Murray and Bertram, 2008; Bodsworth et al., 2010; Song et al., 2013; Ji et al., 2017; Wang et al., 2017).

Recently, a number of studies have investigated viscosity or diffusion rates within SOA particles generated in the laboratory (Virtanen et al., 2010; Cappa et al., 2011; Perraud et al., 2012; Saukko et al., 2012; Abramson et al., 2013; Robinson et al., 2013; Renbaum-Wolff et al., 2013; Loza et al., 2013; Kidd et al., 2014; Pajunoja et al., 2014; Bateman et al., 2015; Li et al., 2015; Song et al., 2015; M. Song et al., 2016; Wang et al., 2015; Zhang et al., 2015; Grayson et al., 2016; Liu et al., 2016; Ye et al., 2018; Ullmann et al., 2019). Almost all of these studies focused on SOA generated from a single VOC. Additional studies that quantify the viscosity of SOA generated from a complex mixture of VOCs of atmospheric relevance are also needed.

Functional group contribution methods have recently been used to predict viscosities within organic matrices of atmospheric relevance (M. Song et al., 2016; Y. C. Song et al.,
2016; Grayson et al., 2017; Rothfuss and Petters, 2017). Methods have also been developed to predict the glass transition temperature and viscosity within an organic matrix of atmospheric relevance using molar mass and oxygen to carbon elemental ratio (O:C) (Shiraiwa et al., 2017) or the number of carbon, hydrogen, and oxygen atoms of the organic compounds within the organic matrix (DeRieux et al., 2018). These methods, if accurate, should be useful for predicting viscosity of SOA particles in the atmosphere.

Diesel fuel contains a wide range of VOCs including aromatics and alkanes. Furthermore, SOA generated from the photooxidation of diesel fuel vapors may be a good proxy for SOA from anthropogenic emissions (Odum et al., 1997; Schauer et al., 2002a, b; Vutukuru et al., 2006; Velasco et al., 2007, 2009; de Gouw et al., 2008; Gentner et al., 2012, 2017; Liu et al., 2012; Jathar et al., 2013, 2014; Hayes et al., 2015; Blair et al., 2017; Jathar et al., 2017). In this study, we investigate LLPS and viscosity within SOA particles generated by photooxidation of diesel fuel vapors. Measured viscosities are also compared with predicted viscosities based on the methods developed by Shiraiwa et al. (2017) and DeRieux et al. (2018). Based on the measured viscosities and the Stokes-Einstein relation, diffusion coefficients and mixing times of large organic molecules within diesel fuel SOA were also estimated.

\section{Experimental}

\subsection{SOA generation}

SOA from the photooxidation of diesel fuel vapors was produced in an identical manner to that described previously (DSL/ $/ \mathrm{NO}_{x}$ in Table 1 of Blair et al., 2017). A volume of $45 \mu \mathrm{L}$ of $\mathrm{H}_{2} \mathrm{O}_{2}(30 \mathrm{wt} \%)$ was evaporated in a $5.6 \mathrm{~m}^{3}$ inflatable Teflon chamber to achieve a mixing ratio of $2 \mathrm{ppmv}$ (parts per million by volume). A mixture of $\mathrm{NO}$ in $\mathrm{N}_{2}$ was injected from a gas cylinder to achieve $0.26 \mathrm{ppmv}$ of NO in the chamber. A volume of $200 \mu \mathrm{L}$ of diesel fuel (Fluka. No. 2 UST-148, $50 \mathrm{mg} \mathrm{mL}^{-1}$ solution of diesel fuel in dichloromethane) was evaporated in the chamber, resulting in a concentration of $1.8 \mathrm{mg} \mathrm{m}^{-3}$ organic vapor from diesel and a mixing ratio of $0.22 \mathrm{ppmv}$ (based on an average molecular weight of $200 \mathrm{~g} \mathrm{~mol}^{-1}$ (Blair et al., 2017) and assuming no wall loss). No seed aerosol was used, and the chamber RH was below $2 \%$. UV-B lamps (FS40T12/UVB, Solarc Systems Inc.) were used to drive the photooxidation, which lasted for $3 \mathrm{~h}$, followed by particle collection. After $3 \mathrm{~h}$ of photooxidation, the particle mass loading in the chamber was $550 \mu \mathrm{g} \mathrm{m}^{-3}$ based on measurements with a scanning mobility particle sizer (SMPS; TSI 3080 electrostatic classifier and TSI 3775 condensation particle counter). An Aerodyne time-of-flight aerosol mass spectrometer (ToF-AMS) was used to measure the particle mass spectra in $\mathrm{V}$ mode. ToF-AMS data were analyzed using Squirrel version 1.61. 
For elemental analysis, we relied on the improved-ambient method by Canagaratna et al. (2015). Figure S1 in the Supplement shows typical particle number concentration, mass concentration, and average atomic ratios during the photooxidation. The $\mathrm{O}: \mathrm{C}$ values $(0.4$ to 0.5$)$ were consistent with $\mathrm{O}: \mathrm{C}$ values reported by Blair et al. (2017) for identically prepared samples.

For the LLPS and viscosity measurements, the SOA from the chamber was collected on hydrophobic glass slides (12 mm coverslips, Hampton Research, Canada) for $120 \mathrm{~min}$ using an inertial impactor. To make the surface of the glass slides hydrophobic, they were coated with trichloro( $1 H, 1 H, 2 H, 2 H$-perfluorooctyl)silane (Sigma-Aldrich) following the procedure reported in Knopf (2003). After collection, the sizes of the SOA particles on the hydrophobic glass slides were $>10 \mu \mathrm{m}$. These large sizes were formed by impaction and coagulation of the SOA during collection.

\subsection{Measurements of LLPS}

SOA was collected on hydrophobic glass slides by impaction, resulting in SOA particles on the hydrophobic glass slides with diameters $>10 \mu \mathrm{m}$ and a spherical cap geometry. LLPS was detected using an optical microscope (Zeiss Epiplan 10X/0.20 HD) coupled to a flow cell with temperature and RH control (Parsons et al., 2004; Pant et al., 2006; Song et al., 2012b). During the experiments, a constant flow $\left(1.5 \mathrm{~L} \mathrm{~min}^{-1}\right)$ of humidified $\mathrm{N}_{2}$ gas was maintained within the flow cell and measured with a dew point hygrometer (General Eastern M4/E4 dew point monitor, Canada). The temperature within the flow cell was maintained at $290 \pm 1 \mathrm{~K}$ and measured with a thermocouple (OMEGA, Canada). At the beginning of the experiments, the SOA particles were equilibrated at around $100 \% \mathrm{RH}$ for at least $15 \mathrm{~min}$. At this point, the focus of the microscope was adjusted so the focal plane of the microscope corresponded to the top or interior of several SOA particles. Due to the different sizes of the SOA particles on the hydrophobic glass slides, the focal plane of the microscope corresponded to the top of some SOA particles and the middle of some SOA particles while some smaller particles were not in the focal plane (leading to blurry images). Next, the RH was reduced at a rate of $0.5 \% \mathrm{RH} \mathrm{min}^{-1}$ until a value close to $0 \%$ was reached. While the RH was decreased, images of the particles were acquired every $10 \mathrm{~s}$ with a CCD (charge-coupled device) camera connected to the microscope. From the images, the number of phases (e.g., one phase or two phases) present in the particles were determined. Typically the focus of the microscope was not adjusted as the RH was reduced. As the RH was reduced, the size of the SOA particles decreased due to the loss of water, and some SOA particles that were in focus at high- $\mathrm{RH}$ values became out of focus at low- $\mathrm{RH}$ values.

\subsection{Measurements of particle viscosity}

The viscosity of the collected particles was determined using the poke-and-flow technique, which has been described by Renbaum-Wolff et al. (2013) and Grayson et al. (2015), and based, in part, on the earlier experiments by Murray et al. (2012). In short, the SOA particles collected on hydrophobic glass slides were placed inside a flow cell with RH and temperature control (Pant et al., 2006; Bertram et al., 2011; Song et al., 2012a). After conditioning the particles to a known RH at $294 \pm 1 \mathrm{~K}$, the particles were poked with a sharp needle $(\sim 10 \mu \mathrm{m}$ for the tip of the needle) (Becton, Dickinson and Company, USA). The movement of the needle was controlled with a micromanipulator (Narishige, model MO-202U, Japan). The change in morphology as a function of time after poking the particles with the needle was recorded with a camera attached to the microscope. From the morphology changes and fluid dynamics simulations, upper and lower limits to the SOA viscosity were determined. Fluid dynamics simulations were performed using the finiteelement analysis software package, COMSOL Multiphysics (Renbaum-Wolff et al., 2013; Grayson et al., 2015). The geometry used in the simulations was based on the geometry of the particles after poking them with a needle. Additional details of the poke-and-flow experiments and the fluid dynamics simulations are discussed in Sect. 3.2 and Sects. S1-S3 of the Supplement.

We acknowledge that viscosity of the SOA could change between the time of its initial formation in the chamber and the time of the offline viscosity and LLPS measurements. Such changes can be driven by both evaporative losses and slow chemical aging processes. During the MOUDI (microorifice uniform deposit impactor) sampling, impacted particles are surrounded by the same gaseous products as in the chamber and should not evaporate. We expect the evaporation to be minimal when the collected particles are briefly exposed to ambient air, sealed in a storage container with a small headspace volume $\left(\sim 2 \mathrm{~cm}^{3}\right)$, and frozen for storage and shipment. However, in the poke-and-flow experiments (as well as the LLPS experiments), the particles are exposed to a constant flow of purified air at room temperature for an extended period of time, which can lead to a change in the composition of the particles by partitioning of semivolatiles to the gas phase. For a $1 \mathrm{~h}$ poke-and-flow experiment, the amount of gas exposed to the SOA is $30 \mathrm{~L}$ compared to $380 \mathrm{~L}$ collected from the environmental chamber. For a $27 \mathrm{~h}$ poke-and-flow experiment (maximum amount of time a sample was exposed to a constant gas flow), the amount of gas exposed to the SOA was $810 \mathrm{~L}$ compared to $380 \mathrm{~L}$ collected from the environmental chamber. We did not observe a relationship between particle viscosity and time the SOA was exposed to a constant flow of gas in our experiments; however, semivolatiles may still have evaporated in the experiments when the particles were conditioned to a known RH and during the poke-and-flow measurements. 
The loss of semivolatiles would lead to an increase in viscosity of the SOA (Wilson et al., 2015; Yli-Juuti et al., 2017; Buchholz et al., 2019). Consequently, our results should be considered upper limits to the viscosity of the SOA generated with a particle mass loading of $550 \mu \mathrm{g} \mathrm{m}^{-3}$. The evaporation of semivolatiles in the experiments as well as possible slow chemical aging reactions occurring during shipment and storage may in fact have resulted in the SOA being more similar to the chemical composition of SOA in the atmosphere, which are formed at particle mass loadings $<550 \mu \mathrm{g} \mathrm{m}^{-3}$ and then chemically aged.

\subsection{Predictions of viscosity based on high-resolution mass spectrometry}

Viscosities of the diesel fuel SOA was predicted using the elemental composition of the SOA and the methods developed by Shiraiwa et al. (2017) and DeRieux et al. (2018). The elemental compositions of the diesel fuel SOA were taken from a previous study (Blair et al., 2017) using SOA generated with identical conditions (DSL/NO $x$ in Table 1 of Blair et al., 2017). In the previous study by Blair et al. (2017) highresolution nanospray desorption electrospray ionization mass spectrometry (Roach et al., 2010) was used to determine the elemental composition.

Shiraiwa et al. (2017) reported a parameterization (Eq. 1) to estimate the glass transition temperature $\left(T_{\mathrm{g}}\right)$ of individual $\mathrm{CH}$ or $\mathrm{CHO}$ compounds with molar mass $<\sim 450 \mathrm{~g} \mathrm{~mol}^{-1}$.

$T_{\mathrm{g}}=A+B M+C M^{2}+D(\mathrm{O}: \mathrm{C})+E M(\mathrm{O}: \mathrm{C})$,

where $M$ is the molar mass and $\mathrm{O}: \mathrm{C}$ is the ratio of oxygen to carbon atoms. The coefficients are $A=-21.57(\mathrm{~K})$, $B=1.51\left(\mathrm{~K} \mathrm{~mol} \mathrm{~g}^{-1}\right), C=-1.7 \times 10^{-3}\left(\mathrm{~K} \mathrm{~mol}^{2} \mathrm{~g}^{-2}\right), D=$ $131.4(\mathrm{~K})$, and $E=-0.25\left(\mathrm{~K} \mathrm{~mol} \mathrm{~g}^{-1}\right)$.

DeRieux et al. (2018) reported another parameterization (Eq. 2) to predict $T_{\mathrm{g}}$ of $\mathrm{CH}$ and $\mathrm{CHO}$ compounds with molar mass up to $\sim 1100 \mathrm{~g} \mathrm{~mol}^{-1}$ using the number of carbon $\left(n_{\mathrm{C}}\right)$, hydrogen $\left(n_{H}\right)$, and oxygen atoms $\left(n_{\mathrm{O}}\right)$ :

$$
\begin{aligned}
T_{\mathrm{g}} & =\left(n_{\mathrm{C}}^{0}+\ln \left(n_{\mathrm{C}}\right)\right) b_{\mathrm{C}}+\ln \left(n_{\mathrm{H}}\right) b_{\mathrm{H}}+\ln \left(n_{\mathrm{C}}\right) \ln \left(n_{\mathrm{H}}\right) b_{\mathrm{CH}} \\
& +\ln \left(n_{\mathrm{O}}\right) b_{\mathrm{O}}+\ln \left(n_{\mathrm{C}}\right) \ln \left(n_{\mathrm{O}}\right) b_{\mathrm{CO}} .
\end{aligned}
$$

Values of the coefficients $n_{\mathrm{C}}^{0}, b_{\mathrm{C}}, b_{\mathrm{H}}, b_{\mathrm{CH}}, b_{\mathrm{O}}$, and $b_{\mathrm{CO}}$ are $1.96,61.99,-113.33,28.74,0$, and 0 for $\mathrm{CH}$ compounds and $12.13,10.95,-41.82,21.61,118.96$, and -24.38 for $\mathrm{CHO}$ compounds, respectively (DeRieux et al., 2018).

To estimate the $T_{\mathrm{g}}$ for a dry organic mixture $\left(T_{\mathrm{g}, \mathrm{org}}\right)$, the relative mass concentration of each compound was assumed to be proportional to its relative abundance in the mass spectrum and the Gordon-Taylor mixing rule was employed with a Gordon-Taylor coefficient $\left(k_{\mathrm{GT}}\right)$ value of 1 , as done previously for organic-organic mixtures (Dette et al., 2014).

For the $T_{\mathrm{g}}$ of a mixture of organics and water $\left(T_{\mathrm{g}, \mathrm{mix}}\right)$, the effective hygroscopicity parameter $(\kappa)$ was applied to calculate the mass fraction of water in the SOA particles (Petters and Kreidenweis, 2007). A $\kappa$ value of 0.1 was used for the diesel fuel SOA based on an average O : C of 0.45 for dieselfuel-derived SOA (Fig. S1 and Table S2 in Blair et al., 2017) and the relationship between $\mathrm{O}: \mathrm{C}$ and $\kappa$ reported in Lambe et al. (2011, Fig. 7) and Massoli et al. (2010, Fig. 2). To estimate the $T_{\mathrm{g}, \mathrm{mix}}$, the Gordon-Taylor equation was applied with $k_{\mathrm{GT}}$ set to 2.5 , based on previous studies that suggested $2.5 \pm 1.0$ for organic-water mixtures (Zobrist et al., 2008; Koop et al., 2011; Berkemeier et al., 2014).

Once $T_{\mathrm{g} \text {,mix }}$ was determined, viscosity was estimated using the modified Vogel-Tammann-Fulcher (VTF) equation and an assumed viscosity of $10^{12} \mathrm{~Pa}$ at the glass transition temperature $\left(T=T_{\mathrm{g}}\right)$ and an assumed viscosity of $10^{-5} \mathrm{~Pa} \mathrm{~s}$ at a very high temperature:

$\log \eta=-5+0.434 \frac{T_{0} D_{\mathrm{f}}}{T-T_{0}}$,

where

$T_{0}=\frac{39.17 T_{\mathrm{g}}}{D_{\mathrm{f}}+39.17}$.

The viscosity of $10^{-5} \mathrm{Pas}$ at a very high temperature is well established in the glass community (Angell, 1991, 2002). In these equations, $D_{\mathrm{f}}$ is the fragility parameter and $T_{0}$ is the Vogel temperature. In our calculations, we fixed $D_{\mathrm{f}}$ to be 10 because a previous study showed that $D_{\mathrm{f}}$ approaches 10 when the molar mass of the organic compounds exceeds $\sim 200 \mathrm{~g} \mathrm{~mol}^{-1}$ (DeRieux et al., 2018) and because many of the detected compounds in diesel SOA have molar masses $>200 \mathrm{~g} \mathrm{~mol}^{-1}$. Even though the $D_{\mathrm{f}}$ value does affect predicted viscosity (see Fig. $5 \mathrm{~b}$ in DeRieux et al., 2018), $D_{\mathrm{f}}$ is not as critical as other parameters such as the glass transition temperature or hygroscopicity.

\section{Results and discussion}

\subsection{LLPS in diesel fuel SOA}

Figures 1 and S2 show examples of images recorded during the LLPS experiments as the RH was decreased from $\sim 100 \%$ to $\sim 0 \%$. The five particles shown in Figs. 1 and $\mathrm{S} 2$ were produced with the same reaction conditions. At the highest RH values $(\sim 100 \%)$, two phases were observed in all cases. The inner phase was most likely a water-rich phase while the outer phase was likely an organic-rich phase since the inner phase decreased in size as the RH decreased. This conclusion is consistent with surface tensions of organics and experiments that have investigated morphology of particles after LLPS (Jasper, 1972; Kwamena et al., 2010; Reid et al., 2011; Song et al., 2013; O’Brien et al., 2015; Gorkowski et al., 2016, 2017). The organic-rich phase was most likely noncrystalline since SOA contains thousands of molecules and the concentration of any individual molecule is likely below the concentration required for crystallization (Marcolli et al., 


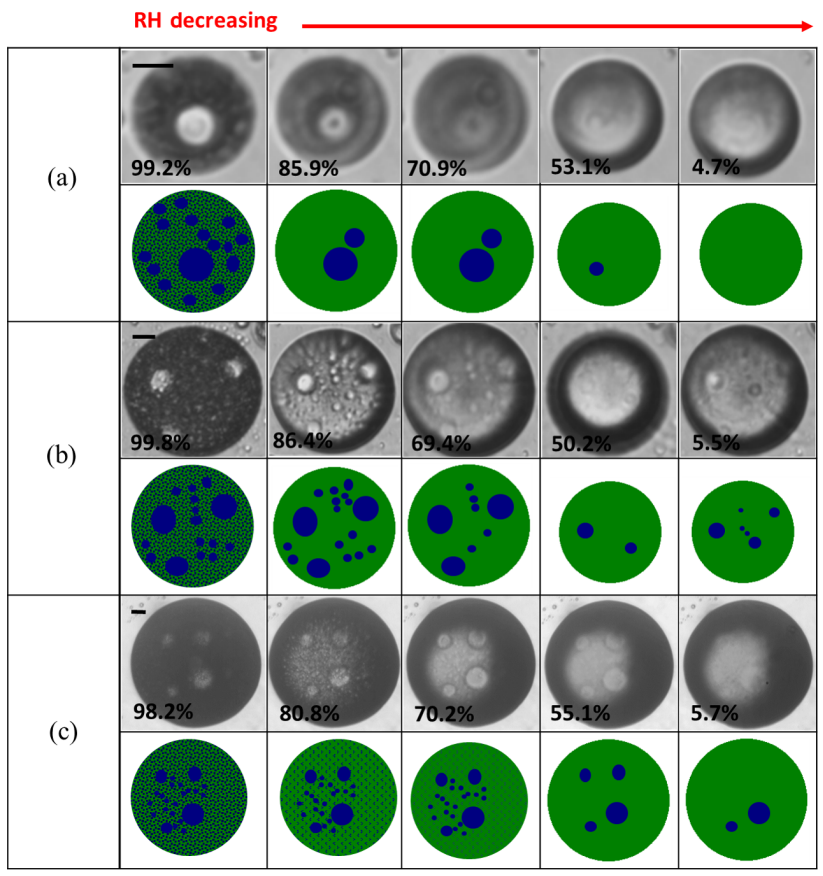

Figure 1. Optical images and illustrations of three diesel fuel SOA particles taken while the RH was decreased. Illustrations are provided to help interpret the optical images with green color representing the organic-rich phase and blue color representing the water-rich phase. The numbers under the optical images indicate the RH. The length of the scale bar is $10 \mu \mathrm{m}$.

2004). At $\sim 70 \% \mathrm{RH}$, two liquid phases remained in all particles (Figs. 1 and S2). Small amounts of the water-rich phase were present even at $50 \%$ RH in most cases (Figs. 1 and S2). In the few cases where LLPS was not observed at $50 \% \mathrm{RH}$, two liquid phases may still have been present in the particles but not in the focus of the microscope.

In the previous studies using SOA derived from a single VOC, LLPS was observed when the average $\mathrm{O}: \mathrm{C}$ was between 0.34 and 0.44 but not when the average $\mathrm{O}: \mathrm{C}$ was between 0.52 and 1.30 (Renbaum-Wolff et al., 2016; Rastak et al., 2017; Song et al., 2017). Consistent with this trend, in the current studies, we observed LLPS when the $\mathrm{O}: \mathrm{C}$ values of the SOA were 0.4-0.5 (Fig. S1b). However, in the previous studies using SOA derived from a single VOC, LLPS was only observed between $\sim 95 \%$ and close to $\sim 100 \% \mathrm{RH}$, whereas in the current study LLPS was observed between $\sim 70 \%$ and close to $\sim 100 \%$. This suggests that as the complexity of SOA increases, LLPS can occur over a wider range of RH values. Consistent with this conclusion, in a recent study, we showed that LLPS in organic particles containing two commercially available organic compounds occurs over a wider RH range than in particles containing only one organic compound (Song et al., 2018).

The increase in the range of RH values over which LLPS occurs is likely related to the distribution of the polarities (or

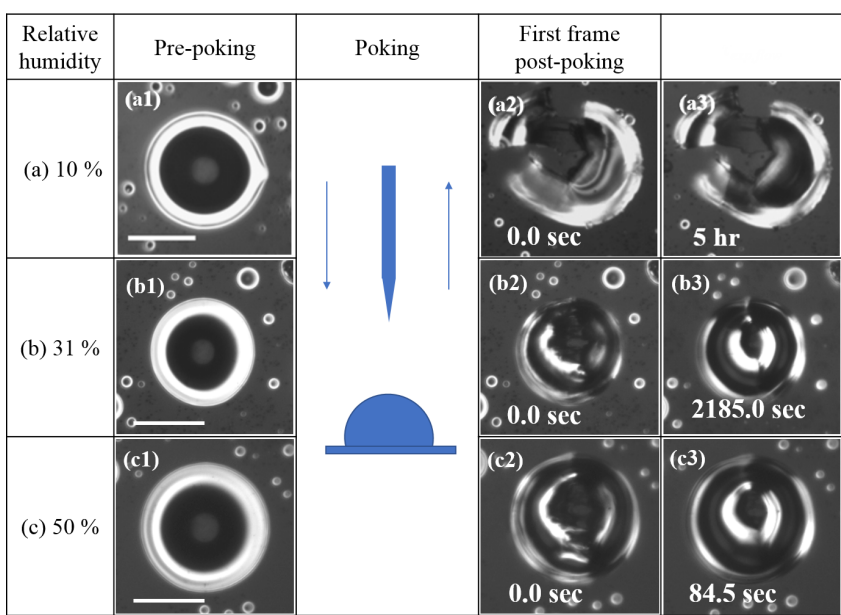

Figure 2. Optical images of SOA particles during a poke-and-flow experiment: (a) $10 \% \mathrm{RH}$, (b) $31 \% \mathrm{RH}$, and (c) $50 \% \mathrm{RH}$. The size of the scale bar is $20 \mu \mathrm{m}$.

hydrophilicities) of the organic molecules within the SOA (Renbaum-Wolff et al., 2016; Gorkowski et al., 2019). When the organic molecules are hydrophobic or moderately hydrophobic (and hence have small $\mathrm{O}: \mathrm{C}$ values), the particles are expected to have a single organic-rich phase until close to $100 \% \mathrm{RH}$, at which point LLPS can occur. When the organic molecules are hydrophilic (and hence have large $\mathrm{O}: \mathrm{C}$ values), the particles are expected to have a single water-rich phase, with no occurrence of LLPS. Alternatively, if the particles contain a mixture of hydrophobic and hydrophilic organic molecules, the particles are expected to have both an organic-rich phase and a water-rich phase over a relatively wide range of RH values. A significant amount of molecules with low and high $\mathrm{O}: \mathrm{C}$ values in the diesel SOA studied here (Fig. S3) is consistent with LLPS being observed over a relatively wide range of $\mathrm{RH}$ values.

\subsection{Viscosity of diesel-fuel-derived SOA}

\subsubsection{Lower limits to viscosity at $10 \% \mathrm{RH}$}

In these experiments, the RH was first decreased to $10 \%$ and particles were conditioned at this RH for approximately $1 \mathrm{~h}$. After conditioning, the particles were poked with a needle, which caused the particles to crack (Fig. 2a). After poking, the sharp edges that resulted from cracking moved by less than $0.5 \mu \mathrm{m}$ in $5 \mathrm{~h}$. The distance of $0.5 \mu \mathrm{m}$ corresponds to the minimum amount of movement that could be discerned in our microscope setup. Based on these results and fluid dynamics simulations (Sect. S1 in the Supplement), the lower limit to the viscosity at $10 \% \mathrm{RH}$ is $1 \times 10^{8} \mathrm{~Pa} \mathrm{~s}$ (Fig. 3a). This corresponds to roughly the viscosity of tar pitch (Koop et al., 2011). 


\subsubsection{Lower limits to viscosity at $31 \% \mathrm{RH}$ and $50 \%$ RH}

In these experiments, the RH was first decreased to $31 \%$ or $50 \%$ and conditioned at these RH values for 1 and $0.5 \mathrm{~h}$, respectively. After conditioning the particles at either $31 \% \mathrm{RH}$ or $50 \% \mathrm{RH}$, they were poked with a needle, resulting in the formation of a half-torus geometry (Fig. 2b and c). From images recorded after poking the particles, the experimental flow time, $\tau_{\text {exp,flow }}$, was determined, which corresponds to the time for the equivalent-area diameter of the inside of the half-torus geometry to reduce by $50 \%$. The equivalentarea diameter, $d$, was calculated via the relationship $d=$ $(4 A / \pi)^{1 / 2}$, where $A$ is the hole area (Reist, 1992). Based on the measured $\tau_{\text {exp,flow }}$ values and fluid dynamics simulations (Renbaum-Wolff et al., 2013; Grayson et al., 2015), and Sect. S2 in the Supplement, the lower limit to the viscosity is approximately $3 \times 10^{4}$ and $8 \times 10^{5} \mathrm{Pas}$ at $50 \%$ and $31 \%$ RH, respectively (Fig. 3a). For reference, the viscosity of peanut butter corresponds to approximately $10^{3} \mathrm{~Pa} \mathrm{~s}$ (Koop et al., 2011).

\subsubsection{Upper limits to viscosity at $\mathrm{RH}$ values ranging from $38 \%$ to $60 \%$}

In these experiments, the following new procedure was used. First, the particles were exposed to a dry nitrogen flow at $0 \% \mathrm{RH}$ for $\sim 1 \mathrm{~h}$. After this exposure, the particles were poked with a needle resulting in cracking of the particles. The $\mathrm{RH}$ above the particles was then increased in a single step to one of the following RH values: $38 \%, 41 \%, 48 \%$, $53 \%, 57 \%$, or $60 \%$. As the RH increased and then stabilized (which took 5-10 min), the cracked particles began to flow and returned to an approximately spherical cap shape (e.g., Fig. 4). From images recorded during these experiments, the time required for the particles to return to a spherical cap shape (starting from the cracked particles at $\mathrm{RH}=0 \%$ ) was determined. This time (which included the time for the RH to increase and stabilize) was referred to as the experimental recovery time, $\tau_{\text {exp,recovery }}$. Based on the $\tau_{\text {exp,recovery }}$ values and fluid dynamics simulations (Sect. S3 in the Supplement), the upper limits of the viscosity are $\sim 1 \times 10^{7}$ and $\sim 1 \times 10^{8} \mathrm{~Pa} \mathrm{~s}$ at RH values of $60 \%$ and $38 \%$, respectively (Fig. 3a).

\subsubsection{Comparison with previous measurements and predictions}

In Fig. $3 b$ the measured viscosities determined from individual poke-and-flow experiments are grouped by $\mathrm{RH}$ and compared with the viscosity of SOA generated by the photooxidation of toluene. Toluene SOA is commonly used as a proxy of anthropogenic SOA (Pandis et al., 1992; Robinson et al., 2013; Bateman et al., 2015; Liu et al., 2016; M. Song et al., 2016). The viscosities of the toluene SOA and the diesel fuel SOA are similar. At RH values between $38 \%$ and $50 \%$ both
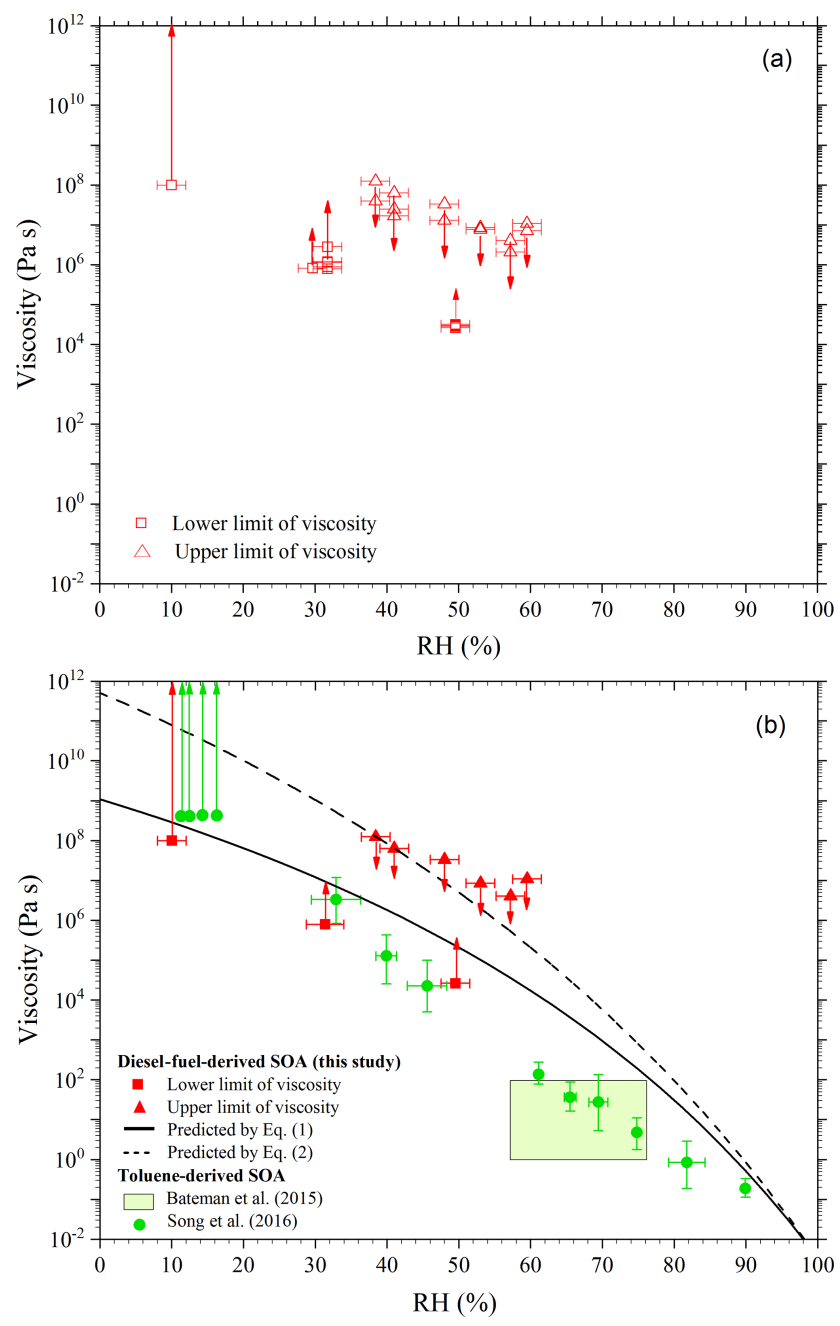

Figure 3. (a) Viscosities of diesel fuel SOA. Each data point corresponds to a viscosity determined from poking a single and different particle. Each particle was prepared with the same reaction conditions. Upward arrows indicate lower limit to the viscosities and downward arrows indicate upper limit to the viscosities of diesel fuel SOA. The $x$ error bars represent uncertainty in the RH measurements. (b) Viscosities of diesel fuel SOA but with the viscosities from individual poke-and-flow experiments grouped by RH. The lower limit to the viscosities and the upper limit to the viscosities represent the lowest and the highest viscosities in the group, respectively. At least two data points were included in each group. The $x$ error bars represent the lowest and highest $\mathrm{RH}$ ranges in the group and the uncertainty in the RH measurements. Also included are viscosities of toluene SOA from Bateman et al. (2015) (green box) and M. Song et al. (2016) (green circle symbols) and predicted viscosities of the diesel fuel SOA using Eq. (1) (solid black line) and Eq. (2) (dashed black line).

have viscosities in the range of approximately $10^{4}$ to $10^{8} \mathrm{~Pa}$, while at $\leq 10 \%$ RH both have viscosities $\geq 1 \times 10^{8} \mathrm{Pas}$.

In Fig. 3b, the viscosity of diesel fuel SOA is also compared with predicted viscosities based on $\mathrm{O}: \mathrm{C}$ and molar mass (Eq. 1) as well as the number of carbon, hydrogen, and 


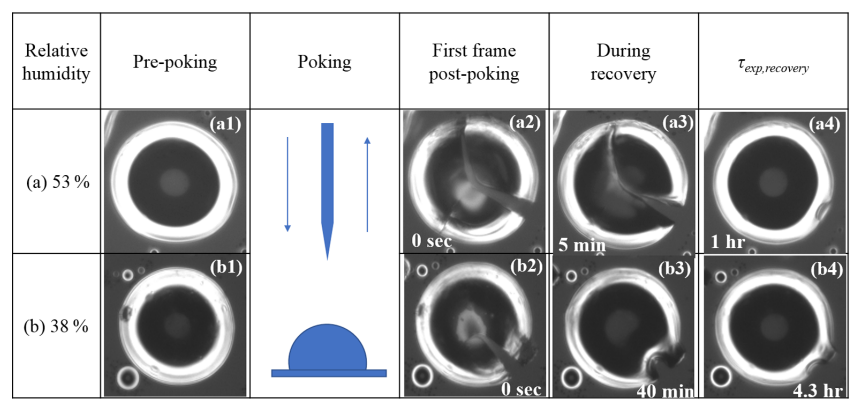

Figure 4. Optical images of diesel fuel SOA particles during pokeand-flow experiments. In these experiments the SOA particles were poked at $0 \% \mathrm{RH}$ and then exposed to $\mathrm{RH}$ values of $53 \%$ (a) and $38 \%$ (b). The last column shows the particles after they have returned to a spherical cap shape.

oxygen atoms (Eq. 2). Within the uncertainty of the measurements, the predicted viscosities are consistent with the measured viscosities (Fig. 3b). Measurements of viscosity with reduced uncertainties would be useful to better test the predictions. Common methods used to measure viscosities (i.e., bulk viscometers) are more precise than the poke-and-flow technique but require more material than is typically produced in environmental chambers (Reid et al., 2018).

Interestingly, predictions based on the number of carbon, hydrogen, and oxygen atoms (Eq. 2) are almost 3 orders of magnitude higher than predictions based on $\mathrm{O}: \mathrm{C}$ and molar mass (Eq. 1) for dry conditions (i.e., $0 \%$ RH) (Fig. 3b). Equation (2) was applied to molar masses up to $\sim 1100 \mathrm{~g} \mathrm{~mol}^{-1}$, while Eq. (1) was applied to molar masses $<450 \mathrm{~g} \mathrm{~mol}^{-1}$. If Eq. (2) was limited to molar masses $<450 \mathrm{~g} \mathrm{~mol}^{-1}$, the predicted viscosities would only decrease by a factor of $\leq 1.3$ (Fig. S6). The difference in the predictions based on Eqs. (1) and (2) shown in Fig. 3b is due to the uncertainties in those two parameterizations. More comprehensive experimental $T_{\mathrm{g}}$ datasets are needed to further refine the $T_{\mathrm{g}}$ parameterizations.

The predicted viscosities shown in Fig. $3 \mathrm{~b}$ only consider $\mathrm{CH}$ and $\mathrm{CHO}$ compounds. For the diesel fuel SOA studied here, 257 compounds ( $\sim 36 \%$ of the intensity weighted peaks) were CHON compounds (Blair et al., 2017). A comprehensive experimental $T_{\mathrm{g}}$ dataset for organic compounds containing nitrogen atoms is required to improve the viscosity predictions of diesel fuel SOA.

\subsection{Diffusion coefficients and mixing times of large organics within diesel fuel SOA}

From the measured viscosities, we calculated diffusion coefficients of the organic molecules within the diesel fuel SOA using the Stokes-Einstein relation:

$$
D_{\text {org }}=\frac{k T}{6 \pi a \eta}
$$

where $k$ is the Boltzmann constant, $T$ is the temperature, $a$ is the hydrodynamic radius of the diffusing species, and $\eta$ is the dynamic viscosity. To calculate diffusion coefficients, we assumed a hydrodynamic radius of $0.4 \mathrm{~nm}$ for the diffusing organic molecules (Renbaum-Wolff et al., 2013). Although the Stokes-Einstein relation may underpredict diffusion of small molecules (e.g., $\mathrm{OH}, \mathrm{O}_{3}, \mathrm{NO}_{x}, \mathrm{NH}_{3}$, and $\mathrm{H}_{2} \mathrm{O}$ ) in $\mathrm{SOA}$, this equation gives reasonable values when the size of the diffusing organics is similar to the size of the matrix molecules and the temperature is not too close to the $T_{\mathrm{g}}$ of the matrix (Champion et al., 2000; Marshall et al., 2016; Price et al., 2015, 2016; Bastelberger et al., 2017; Chenyakin et al., 2017; Ullmann et al., 2019). Based on the measured viscosities and the Stokes-Einstein relation, the diffusion coefficients of organics within diesel SOA is $\leq 5.4 \times 10^{-17} \mathrm{~cm}^{2} \mathrm{~s}^{-1}$ for RH values $\leq 10 \%$ (Fig. 5a, secondary $y$ axis). For $\mathrm{RH}$ values between $38 \%$ and $50 \%$, the diffusion coefficients are in the range of $5.4 \times 10^{-17}$ to $1.8 \times 10^{-13} \mathrm{~cm}^{2} \mathrm{~s}^{-1}$.

From the calculated $D_{\text {org }}$, the mixing time of organics within $200 \mathrm{~nm}$ diesel fuel SOA particles, $\tau_{\text {mixing }}$, was calculated with the following equation (Seinfeld and Pandis, 2006; Shiraiwa et al., 2011):

$\tau_{\text {mixing }}=\frac{d^{2}}{4 \pi D_{\text {org }}}$,

where $d$ corresponds to the diameter of the SOA particles. Values of $\tau_{\text {mixing }}$ represent the time after which the concentration of the diffusing molecules at the center of the particles deviates by less than $e^{-1}$ from the equilibrium concentration. When calculating $\tau_{\text {mixing, }}$, we assumed $d$ was $200 \mathrm{~nm}$, which is consistent with the median diameter of the volume distribution of SOA in the atmosphere (Martin et al., 2010; Pöschl et al., 2010; Riipinen et al., 2011).

It is often assumed in chemical transport models that organic molecules are well mixed in SOA on the timescale of $1 \mathrm{~h}$. Based on our viscosity results and Eq. (6), $\tau_{\text {mixing }}$ is $50 \mathrm{~h}$ at $\leq 10 \%$ RH (Fig. 5a, secondary $y$ axis). This mixing time is much larger than assumed in chemical transport models. However, in the planetary boundary layer, the RH in not of ten $\leq 10 \%$, at least not when SOA concentrations are significant (Fig. $5 \mathrm{~b}$ and c). Nevertheless, the large $\tau_{\text {mixing values }}$ at $\leq 10 \% \mathrm{RH}$ may be important in laboratory experiments, where SOA is often generated and studied under low-RH conditions on the timescales of minutes to hours. At $38 \%-$ $50 \% \mathrm{RH}, \tau_{\text {mixing }}$ is in the range $\sim 0.01$ to $\sim 50 \mathrm{~h}$ (Fig. 5a). These results provide important constraints on $\tau_{\text {mixing }}$ values within anthropogenic SOA.

Several caveats apply to the calculated $\tau_{\text {mixing }}$ values. First, the diesel fuel SOA was generated using relatively high particle mass concentrations $\left(\sim 500 \mu \mathrm{g} \mathrm{m}^{-3}\right)$. The viscosity of diesel fuel SOA may be higher if generated using lower particle mass concentrations (Grayson et al., 2016; Jain et al., 2018). Second, some of the semivolatiles may have evaporated from the diesel fuel SOA in the poke-and-flow experi- 

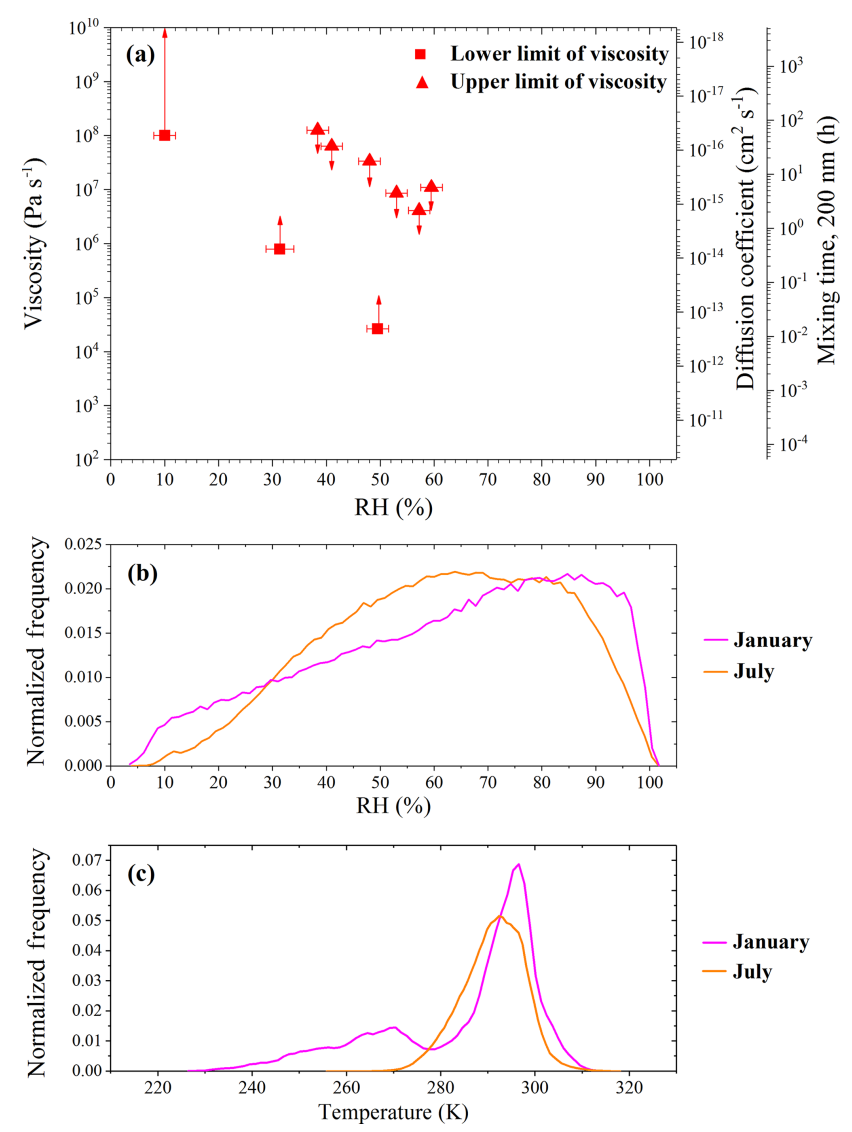

Figure 5. Panel (a) shows viscosities, diffusion coefficients, and mixing times of organic molecules within $200 \mathrm{~nm}$ diesel fuel SOA. Panels (b) and (c) represent the RH frequency distribution and the temperature frequency distribution in the planetary boundary layer when the average concentrations of organic aerosol are higher than $0.5 \mu \mathrm{g} \mathrm{m}^{-3}$ at the surface based on GEOS-Chem (Ullmann et al., 2019). The frequency distributions were calculated using monthly mean meteorological data from GEOS-Chem version v10-01 and data were only included when the monthly mean concentrations of organic aerosol at the surface were greater than $0.5 \mu \mathrm{g} \mathrm{m}^{-3}$ (Maclean et al., 2017).

ments. If evaporation of semivolatiles did occur, the viscosity of the diesel fuel SOA at $\sim 500 \mu \mathrm{g} \mathrm{m}^{-3}$ may be lower than reported here (Wilson et al., 2015; Yli-Juuti et al., 2017;

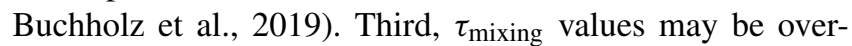
estimated at low-RH values due to the possible breakdown of the Stokes-Einstein relation near the glass transition RH (Champion et al., 2000; Bastelberger et al., 2017; Chenyakin et al., 2017; Evoy et al., 2019; Ullmann et al., 2019). Fourth, when calculating the viscosity, we did not take into account the heterogeneity of the particle (i.e., the presence of both organic-rich and water-rich phases). The viscosity measurements were carried out at $\leq 60 \% \mathrm{RH}$. For this RH range, the amount of the water-rich phase was small but still detectable in most cases. Assuming the water-rich phase is less viscous than the organic-rich phase, due to the plasticizing effect of water, the viscosity of the organic-rich phase will be greater than the calculated (i.e., reported) viscosities.

\section{Summary and conclusions}

We investigated LLPS in SOA generated from diesel fuel vapors. Diesel fuel contains a wide range of VOCs, and diesel fuel SOA may be a reasonable proxy for SOA from anthropogenic emissions. Two liquid phases (an organic-rich outer phase and a water-rich inner phase) were observed in the diesel fuel SOA at $\mathrm{RH}$ values ranging from $\sim 70 \%$ to $\sim 100 \%$. These results may be important for predicting the cloud nucleating ability of anthropogenic SOA since the presence of an organic-rich outer phase at high-RH values can lower the supersaturation with respect to water required for cloud droplet formation (Petters et al., 2006; Hodas et al., 2016; Renbaum-Wolff et al., 2016; Rastak et al., 2017; Ovadnevaite et al., 2017; Liu et al., 2018). The presence of two liquid phases at RH values as low as $\sim 70 \%$ may also impact heterogeneous chemistry, growth, and optical properties of SOA (Zuend et al., 2010; Zuend and Seinfeld, 2012; Shiraiwa et al., 2013b; Freedman, 2017; Fard et al., 2018; Zhang et al., 2018). We conclude that LLPS should be considered when predicting the cloud nucleating ability, reactivity, growth, and optical properties of SOA from anthropogenic emissions.

We also investigated the viscosity of diesel fuel SOA using the poke-and-flow technique together with simulations of fluid flow. For RH values of $\leq 10 \%$, the viscosity was $\geq 1 \times 10^{8} \mathrm{~Pa}$. For RH values between $30 \%$ and $50 \%$, the viscosity was in the range of $1 \times 10^{8}$ to $3 \times 10^{4} \mathrm{Pas}$. The measured viscosities were consistent with predictions based on molar mass and $\mathrm{O}: \mathrm{C}$ ratio as well as predictions based on the number of carbon, hydrogen, and oxygen atoms of identified SOA compounds. Additional measurements of viscosity of diesel fuel SOA with reduced uncertainties would be useful to better test the predictions. Furthermore, additional comprehensive experimental $T_{\mathrm{g}}$ datasets are needed to further refine the parameterizations.

Based on these measured viscosities and the StokesEinstein relation, diffusion coefficients and $\tau_{\text {mixing }}$ values of organics within diesel fuel SOA particles were calculated. For RH values $\leq 10 \%$, diffusion coefficients are $\leq$ $5.4 \times 10^{-17} \mathrm{~cm}^{2} \mathrm{~s}^{-1}$ and $\tau_{\text {mixing }}$ is $50 \mathrm{~h}$. Such low-RH values are not common in the planetary boundary layer but are common in laboratory experiments when generating SOA. We conclude that these large $\tau_{\text {mixing }}$ values should be considered when interpreting laboratory data of SOA generated under low-RH conditions. For RH values between $38 \%$ and $50 \%$, the diffusion coefficients are in the range of $5.4 \times 10^{-17}$ to $1.8 \times 10^{-13} \mathrm{~cm}^{2} \mathrm{~s}^{-1}$ and $\tau_{\text {mixing values are in the range }}$ of $\sim 0.01$ to $\sim 50 \mathrm{~h}$. These results provide important constraints on diffusion coefficients and $\tau_{\text {mixing values within }}$ anthropogenic SOA. Further studies are needed using more 
atmospherically relevant mass concentrations since a relatively high mass concentration $\left(\sim 500 \mu \mathrm{g} \mathrm{m}^{-3}\right)$ of the SOA was used when generating the SOA in this work.

Data availability. Underlying material and related items for this paper are located in the Supplement.

Supplement. The supplement related to this article is available online at: https://doi.org/10.5194/acp-19-12515-2019-supplement.

Author contributions. AKB designed the study. MiS, AMM, and YH performed the viscosity and LLPS experiments. SAN, NRS, SLB, JL, and AL generated the SOA samples and analyzed their chemical compositions. WSWD, YL, and MaS predicted viscosities. MiS and AKB prepared the article with contributions from all co-authors.

Competing interests. The authors declare that they have no conflict of interest.

Acknowledgements. This work was supported by the Natural Sciences and Engineering Research Council of Canada. Mijung Song acknowledges funding from the National Research Foundation of Korea (NRF), the Korea Government (MSIP) (2016R1C1B1009243), and the Korea Institute of Toxicology (KIT) (KK-1905-02). Manabu Shiraiwa acknowledges funding from the US National Science Foundation (AGS-1654104) and the U.S. Department of Energy (DE-SC0018349). The AMS instrument used in this work was acquired with the NSF grant MRI-0923323.

Financial support. This research has been supported by the Natural Sciences and Engineering Research Council of Canada, the National Research Foundation of Korea (NRF) (grant no. 2016R1C1B1009243), the Korea Institute of Toxicology (grant no. KK-1905), the US National Science Foundation (grant no. AGS-1654104), the U.S Department of Energy (grant no. DESC0018349).

Review statement. This paper was edited by Annele Virtanen and reviewed by two anonymous referees.

\section{References}

Abramson, E., Imre, D., Beranek, J., Wilson, J., and Zelenyuk, A.: Experimental determination of chemical diffusion within secondary organic aerosol particles, Phys. Chem. Chem. Phys., 15, 2983-2991, https://doi.10.1039/C2cp44013j, 2013.

Altaft, M. B., Dutcher, D. D., Raymond, T. M., and Freedman, M. A.: Effect of Particle Morphology on Cloud Condensa- tion Nuclei Activity, ACS. Earth Space Chem., 2, 634-639, https://doi.org/10.1021/acsearthspacechem.7b00146, 2018.

Angell, C. A.: Relaxation in liquids, Polymers and plastic crystals Strong fragile patterns and problems, J. Non-Cryst. Solids, 131, 13-31, https://doi.10.1016/0022-3093(91)90266-9, 1991.

Angell, C. A.: Liquid fragility and the glass transition in water and aqueous solutions, Chem. Rev., 102, 2627-2649, https://doi.org/10.1021/cr000689q, 2002.

Baltensperger, U., Dommen, J., Alfarra, R., Duplissy, J., Gaeggeler, K., Metzger, A., Facchini, M. C., Decesari, S., Finessi, E., Reinnig, C., Schott, M., Warnke, J., Hoffmann, T., Klatzer, B., Puxbaum, H., Geiser, M., Savi, M., Lang, D., Kalberer, M., and Geiser, T.: Combined determination of the chemical composition and of health effects of secondary organic aerosols: The POLYSOA project, J. Aerosol Med. Pulm. D, 21, 145-154, 2008.

Bastelberger, S., Krieger, U. K., Luo, B., and Peter, T.: Diffusivity measurements of volatile organics in levitated viscous aerosol particles, Atmos. Chem. Phys., 17, 8453-8471, https://doi.org/10.5194/acp-17-8453-2017, 2017.

Bateman, A. P., Bertram, A. K., and Martin, S. T.: Hygroscopic influence on the semisolid-to-liquid transition of secondary organic materials, J. Phys. Chem. A., 119, 4386-4395, https://doi.org/10.1021/jp508521c, 2015.

Berkemeier, T., Shiraiwa, M., Pöschl, U., and Koop, T.: Competition between water uptake and ice nucleation by glassy organic aerosol particles, Atmos. Chem. Phys., 14, 12513-12531, https://doi.org/10.5194/acp-14-12513-2014, 2014.

Bertram, A. K., Martin, S. T., Hanna, S. J., Smith, M. L., Bodsworth, A., Chen, Q., Kuwata, M., Liu, A., You, Y., and Zorn, S. R.: Predicting the relative humidities of liquid-liquid phase separation, efflorescence, and deliquescence of mixed particles of ammonium sulfate, organic material, and water using the organic-to-sulfate mass ratio of the particle and the oxygen-tocarbon elemental ratio of the organic component, Atmos. Chem. Phys., 11, 10995-11006, https://doi.org/10.5194/acp-11-109952011, 2011.

Blair, S. L., MacMillan, A. C., Drozd, G. T., Goldstein, A. H., Chu, R. K., Pasa-Tolic, L., Shaw, J. B., Tolic, N., Lin, P., Laskin, J., Laskin, A., and Nizkorodov, S. A.: Molecular characterization of organosulfur compounds in biodiesel and diesel fuel secondary organic aerosol, Environ. Sci. Technol., 51, 119-127, https://doi.org/10.1021/acs.est.6b03304, 2017.

Bodsworth, A., Zobrist, B., and Bertram, A. K.: Inhibition of efflorescence in mixed organic-inorganic particles at temperatures less than 250 K, Phys. Chem. Chem. Phys., 12, 15144-15144, 2010.

Buchholz, A., Lambe, A. T., Ylisirniö, A., Li, Z., Tikkanen, O.P., Faiola, C., Kari, E., Hao, L., Luoma, O., Huang, W., Mohr, C., Worsnop, D. R., Nizkorodov, S. A., Yli-Juuti, T., Schobesberger, S., and Virtanen, A.: Insights into the O : C-dependent mechanisms controlling the evaporation of $\alpha$-pinene secondary organic aerosol particles, Atmos. Chem. Phys., 19, 4061-4073, https://doi.org/10.5194/acp-19-4061-2019, 2019.

Canagaratna, M. R., Jimenez, J. L., Kroll, J. H., Chen, Q., Kessler, S. H., Massoli, P., Hildebrandt Ruiz, L., Fortner, E., Williams, L. R., Wilson, K. R., Surratt, J. D., Donahue, N. M., Jayne, J. T., and Worsnop, D. R.: Elemental ratio measurements of organic compounds using aerosol mass spectrometry: characterization, 
improved calibration, and implications, Atmos. Chem. Phys., 15, 253-272, https://doi.org/10.5194/acp-15-253-2015, 2015.

Cappa, C. D. and Wilson, K. R.: Evolution of organic aerosol mass spectra upon heating: implications for OA phase and partitioning behavior, Atmos. Chem. Phys., 11, 1895-1911, https://doi.org/10.5194/acp-11-1895-2011, 2011.

Champion, D., Le Meste, M., and Simatos, D.: Towards an improved understanding of glass transition and relaxations in foods: molecular mobility in the glass transition range, Trends Food Sci. Tech., 11, 41-55, https://doi.10.1016/S0924-2244(00)00047-9, 2000.

Chenyakin, Y., Ullmann, D. A., Evoy, E., Renbaum-Wolff, L., Kamal, S., and Bertram, A. K.: Diffusion coefficients of organic molecules in sucrose-water solutions and comparison with Stokes-Einstein predictions, Atmos. Chem. Phys., 17, 24232435, https://doi.org/10.5194/acp-17-2423-2017, 2017.

Ciobanu, V. G., Marcolli, C., Krieger, U. K., Weers, U., and Peter, T.: Liquid-Liquid Phase Separation in Mixed Organic/Inorganic Aerosol Particles, J. Phys. Chem. A, 113, 10966-10978, https://doi.org/10.1021/Jp905054d, 2009.

Davies, J. F., Zuend, A., and Wilson, K. R.: Technical note: The role of evolving surface tension in the formation of cloud droplets, Atmos. Chem. Phys., 19, 2933-2946, https://doi.org/10.5194/acp19-2933-2019, 2019.

de Gouw, J. A., Brock, C. A., Atlas, E. L., Bates, T. S., Fehsenfeld, F. C., Goldan, P. D., Holloway, J. S., Kuster, W. C., Lerner, B. M., Matthew, B. M., Middlebrook, A. M., Onasch, T. B., Peltier, R. E., Quinn, P. K., Senff, C. J., Stohl, A., Sullivan, A. P., Trainer, M., Warneke, C., Weber, R. J., and Williams, E. J.: Sources of particulate matter in the northeastern United States in summer: 1. Direct emissions and secondary formation of organic matter in urban plumes, J. Geophys. Res.-Atmos., 113, D08301, https://doi.10.1029/2007jd009243, 2008.

DeRieux, W.-S. W., Li, Y., Lin, P., Laskin, J., Laskin, A., Bertram, A. K., Nizkorodov, S. A., and Shiraiwa, M.: Predicting the glass transition temperature and viscosity of secondary organic material using molecular composition, Atmos. Chem. Phys., 18, 6331-6351, https://doi.org/10.5194/acp-18-6331-2018, 2018.

Dette, H. P., Qi, M. A., Schroder, D. C., Godt, A., and Koop, T.: Glass-forming properties of 3-methylbutane-1,2,3-tricarboxylic acid and its mixtures with water and pinonic acid, J. Phys. Chem. A, 118, 7024-7033, https://doi.org/10.1021/jp505910w, 2014.

Ervens, B., Turpin, B. J., and Weber, R. J.: Secondary organic aerosol formation in cloud droplets and aqueous particles (aqSOA): a review of laboratory, field and model studies, Atmos. Chem. Phys., 11, 11069-11102, https://doi.org/10.5194/acp-1111069-2011, 2011.

Evoy, E., Maclean, A. M., Rovelli, G., Li, Y., Tsimpidi, A. P., Karydis, V. A., Kamal, S., Lelieveld, J., Shiraiwa, M., Reid, J. P., and Bertram, A. K.: Predictions of diffusion rates of large organic molecules in secondary organic aerosols using the StokesEinstein and fractional Stokes-Einstein relations, Atmos. Chem. Phys., 19, 10073-10085, https://doi.org/10.5194/acp-19-100732019, 2019.

Fard, M. M., Krieger, U. K., and Peter, T.: Shortwave radiative impact of liquid-liquid phase separation in brown carbon aerosols, Atmos. Chem. Phys., 18, 13511-13530, https://doi.org/10.5194/acp-18-13511-2018, 2018.
Freedman, M. A.: Phase separation in organic aerosol, Chem. Soc. Rev., 46, 7694-7705, https://doi.org/10.1039/c6cs00783j, 2017.

Gentner, D. R., Isaacman, G., Worton, D. R., Chan, A. W. H., Dallmann, T. R., Davis, L., Liu, S., Day, D. A., Russell, L. M., Wilson, K. R., Weber, R., Guha, A., Harley, R. A., and Goldstein, A. H.: Elucidating secondary organic aerosol from diesel and gasoline vehicles through detailed characterization of organic carbon emissions, P. Natl. Acad. Sci. USA, 109, 18318-18323, https://doi.org/10.1073/pnas.1212272109, 2012.

Gentner, D. R., Jathar, S. H., Gordon, T. D., Bahreini, R., Day, D. A., El Haddad, I., Hayes, P. L., Pieber, S. M., Platt, S. M., de Gouw, J., Goldstein, A. H., Harley, R. A., Jimenez, J. L., Prevot, A. S. H., and Robinson, A. L.: Review of Urban Secondary Organic Aerosol Formation from Gasoline and Diesel Motor Vehicle Emissions, Environ. Sci. Technol., 51, 1074-1093, 2017.

Gorkowski, K., Beydoun, H., Aboff, M., Walker, J. S., Reid, J. P., and Sullivan, R. C.: Advanced aerosol optical tweezers chamber design to facilitate phase-separation and equilibration timescale experiments on complex droplets, Aerosol. Sci. Tech., 50, 13271341, https://doi.org/10.1080/02786826.2016.1224317, 2016.

Gorkowski, K., Donahue, N. M., and Sullivan, R. C.: Emulsified and Liquid Liquid Phase-Separated States of alphaPinene Secondary Organic Aerosol Determined Using Aerosol Optical Tweezers, Environ. Sci. Technol., 51, 12154-12163, https://doi.org/10.1021/acs.est.7b03250, 2017.

Gorkowski, K., Preston, T. C., and Zuend, A.: RHdependent organic aerosol thermodynamics via an efficient reduced-complexity model, Atmos. Chem. Phys. Discuss., https://doi.org/10.5194/acp-2019-495, in review, 2019.

Grayson, J. W., Song, M., Sellier, M., and Bertram, A. K.: Validation of the poke-flow technique combined with simulations of fluid flow for determining viscosities in samples with small volumes and high viscosities, Atmos. Meas. Tech., 8, 2463-2472, https://doi.org/10.5194/amt-8-2463-2015, 2015.

Grayson, J. W., Zhang, Y., Mutzel, A., Renbaum-Wolff, L., Böge, O., Kamal, S., Herrmann, H., Martin, S. T., and Bertram, A. $\mathrm{K}$.: Effect of varying experimental conditions on the viscosity of $\alpha$-pinene derived secondary organic material, Atmos. Chem. Phys., 16, 6027-6040, https://doi.org/10.5194/acp-166027-2016, 2016.

Grayson, J. W., Evoy, E., Song, M., Chu, Y., Maclean, A., Nguyen, A., Upshur, M. A., Ebrahimi, M., Chan, C. K., Geiger, F. M., Thomson, R. J., and Bertram, A. K.: The effect of hydroxyl functional groups and molar mass on the viscosity of non-crystalline organic and organic-water particles, Atmos. Chem. Phys., 17, 8509-8524, https://doi.org/10.5194/acp-17-8509-2017, 2017.

Hallquist, M., Wenger, J. C., Baltensperger, U., Rudich, Y., Simpson, D., Claeys, M., Dommen, J., Donahue, N. M., George, C., Goldstein, A. H., Hamilton, J. F., Herrmann, H., Hoffmann, T., Iinuma, Y., Jang, M., Jenkin, M. E., Jimenez, J. L., Kiendler-Scharr, A., Maenhaut, W., McFiggans, G., Mentel, Th. F., Monod, A., Prévôt, A. S. H., Seinfeld, J. H., Surratt, J. D., Szmigielski, R., and Wildt, J.: The formation, properties and impact of secondary organic aerosol: current and emerging issues, Atmos. Chem. Phys., 9, 5155-5236, https://doi.org/10.5194/acp9-5155-2009, 2009.

Ham, S., Babar, Z. B., Lee, J. B., Lim, H.-J., and Song, M.: Liquidliquid phase separation in secondary organic aerosol particles produced from $\alpha$-pinene ozonolysis and $\alpha$-pinene photooxida- 
tion with/without ammonia, Atmos. Chem. Phys., 19, 93219331, https://doi.org/10.5194/acp-19-9321-2019, 2019.

Hayes, P. L., Carlton, A. G., Baker, K. R., Ahmadov, R., Washenfelder, R. A., Alvarez, S., Rappenglück, B., Gilman, J. B., Kuster, W. C., de Gouw, J. A., Zotter, P., Prévôt, A. S. H., Szidat, S., Kleindienst, T. E., Offenberg, J. H., Ma, P. K., and Jimenez, J. L.: Modeling the formation and aging of secondary organic aerosols in Los Angeles during CalNex 2010, Atmos. Chem. Phys., 15, 5773-5801, https://doi.org/10.5194/acp-15-5773-2015, 2015.

Hodas, N., Zuend, A., Schilling, K., Berkemeier, T., Shiraiwa, M., Flagan, R. C., and Seinfeld, J. H.: Discontinuities in hygroscopic growth below and above water saturation for laboratory surrogates of oligomers in organic atmospheric aerosols, Atmos. Chem. Phys., 16, 12767-12792, https://doi.org/10.5194/acp-1612767-2016, 2016

Houle, F. A., Hinsberg, W. D., and Wilson, K. R.: Oxidation of a model alkane aerosol by $\mathrm{OH}$ radical: the emergent nature of reactive uptake, Phys. Chem. Chem. Phys., 17, 4412-4423, 2015.

Jain, S., Fischer, K. B., and Petrucci, G. A.: The Influence of absolute mass loading of secondary organic aerosols on their phase state, Atmosphere-Basel, 9, 131, https://doi.org/10.3390/atmos9040131, 2018.

Jang, M., Ghio, A. J., and Cao, G.: Exposure of BEAS-2B cells to secondary organic aerosol coated on magnetic nanoparticles, Chem. Res. Toxicol., 19, 1044-1050, 2006.

Jasper, J. J.: The surface tension of pure liquid compounds, J. Phys. Chem. Ref. Data, 1, 841-1009, https://doi.org/10.1063/1.3253106, 1972.

Jathar, S. H., Miracolo, M. A., Tkacik, D. S., Donahue, N. M., Adams, P. J., and Robinson, A. L.: Secondary organic aerosol formation from photo-oxidation of unburned fuel: Experimental results and implications for aerosol formation from combustion emissions, Environ. Sci. Technol., 47, 12886-12893, 2013.

Jathar, S. H., Donahue, N. M., Adams, P. J., and Robinson, A. L.: Testing secondary organic aerosol models using smog chamber data for complex precursor mixtures: influence of precursor volatility and molecular structure, Atmos. Chem. Phys., 14, 5771-5780, https://doi.org/10.5194/acp-14-5771-2014, 2014.

Jathar, S. H., Heppding, C., Link, M. F., Farmer, D. K., Akherati, A., Kleeman, M. J., de Gouw, J. A., Veres, P. R., and Roberts, J. M.: Investigating diesel engines as an atmospheric source of isocyanic acid in urban areas, Atmos. Chem. Phys., 17, 89598970, https://doi.org/10.5194/acp-17-8959-2017, 2017.

Ji, Z. R., Zhang, Y., Pang, S. F., and Zhang, Y. H.: Crystal nucleation and crystal growth and mass transfer in internally mixed sucrose $/ \mathrm{NaNO}_{3}$ particles, J. Phys. Chem. A, 121, 7968-7975, https://doi.org/10.1021/acs.jpca.7b08004, 2017.

Jimenez, J. L., Canagaratna, M. R., Donahue, N. M., Prevot, A. S. H., Zhang, Q., Kroll, J. H., DeCarlo, P. F., Allan, J. D., Coe, H., Ng, N. L., Aiken, A. C., Docherty, K. S., Ulbrich, I. M., Grieshop, A. P., Robinson, A. L., Duplissy, J., Smith, J. D., Wilson, K. R., Lanz, V. A., Hueglin, C., Sun, Y. L., Tian, J., Laaksonen, A., Raatikainen, T., Rautiainen, J., Vaattovaara, P., Ehn, M., Kulmala, M., Tomlinson, J. M., Collins, D. R., Cubison, M. J., Dunlea, E. J., Huffman, J. A., Onasch, T. B., Alfarra, M. R., Williams, P. I., Bower, K., Kondo, Y., Schneider, J., Drewnick, F., Borrmann, S., Weimer, S., Demerjian, K., Salcedo, D., Cottrell, L., Griffin, R., Takami, A., Miyoshi, T., Hatakeyama, S., Shimono, A., Sun, J. Y., Zhang, Y. M., Dzepina,
K., Kimmel, J. R., Sueper, D., Jayne, J. T., Herndon, S. C., Trimborn, A. M., Williams, L. R., Wood, E. C., Middlebrook, A. M., Kolb, C. E., Baltensperger, U., and Worsnop, D. R.: Evolution of organic aerosols in the atmosphere, Science, 326, 1525-1529, https://doi.10.1126/science.1180353, 2009.

Kanakidou, M., Seinfeld, J. H., Pandis, S. N., Barnes, I., Dentener, F. J., Facchini, M. C., Van Dingenen, R., Ervens, B., Nenes, A., Nielsen, C. J., Swietlicki, E., Putaud, J. P., Balkanski, Y., Fuzzi, S., Horth, J., Moortgat, G. K., Winterhalter, R., Myhre, C. E. L., Tsigaridis, K., Vignati, E., Stephanou, E. G., and Wilson, J.: Organic aerosol and global climate modelling: a review, Atmos. Chem. Phys., 5, 1053-1123, https://doi.org/10.5194/acp-5-10532005, 2005.

Kidd, C., Perraud, V., Wingen, L. M., and Finlayson-Pitts, B. J.: Integrating phase and composition of secondary organic aerosol from the ozonolysis of alpha-pinene, P. Natl. Acad. Sci. USA, 111, 7552-7557, https://doi.10.1073/pnas.1322558111, 2014.

Kim, Y., Sartelet, K., and Couvidat, F.: Modeling the effect of nonideality, dynamic mass transfer and viscosity on SOA formation in a 3-D air quality model, Atmos. Chem. Phys., 19, 1241-1261, https://doi.org/10.5194/acp-19-1241-2019, 2019.

Knopf, D. A.: Thermodynamic properties and nucleation processes of upper tropospheric and lower stratospheric aerosol particles, Diss. ETH No. 15103, Zurich, Switzerland, 2003.

Knopf, D. A., Alpert, P. A., and Wang, B. B.: The Role of Organic Aerosol in Atmospheric Ice Nucleation: A Review, Acs. Earth Space Chem., 2, 168-202, https://doi.org/10.1021/acsearthspacechem.7b00120, 2018.

Koop, T., Bookhold, J., Shiraiwa, M., and Poschl, U.: Glass transition and phase state of organic compounds: dependency on molecular properties and implications for secondary organic aerosols in the atmosphere, Phys. Chem. Chem. Phys., 13, 19238-19255, https://doi.10.1039/C1cp22617g, 2011.

Krieger, U. K., Marcolli, C., and Reid, J. P.: Exploring the complexity of aerosol particle properties and processes using single particle techniques, Chem. Soc. Rev., 41, 6631-6662, https://doi.org/10.1039/c2cs35082c, 2012.

Kwamena, N. O. A., Buajarern, J., and Reid, J. P.: Equilibrium Morphology of Mixed Organic/Inorganic/Aqueous Aerosol Droplets: Investigating the effect of RH and surfactants, J. Phys. Chem. A, 114, 5787-5795, https://doi.org/10.1021/Jp1003648, 2010.

Ladino, L. A., Zhou, S., Yakobi-Hancock, J. D., Aljawhary, D., and Abbatt, J. P. D.: Factors controlling the ice nucleating abilities of alpha-pinene SOA particles, J. Geophys. Res.-Atmos., 119, 9041-9051, 2014.

Lambe, A. T., Onasch, T. B., Massoli, P., Croasdale, D. R., Wright, J. P., Ahern, A. T., Williams, L. R., Worsnop, D. R., Brune, W. H., and Davidovits, P.: Laboratory studies of the chemical composition and cloud condensation nuclei (CCN) activity of secondary organic aerosol (SOA) and oxidized primary organic aerosol (OPOA), Atmos. Chem. Phys., 11, 8913-8928, https://doi.org/10.5194/acp-11-8913-2011, 2011.

Li, Y. J., Liu, P., Gong, Z., Wang, Y., Bateman, A. P., Bergoend, C., Bertram, A. K., and Martin, S. T.: Chemical reactivity and liquid/nonliquid states of secondary organic material, Environ. Sci. Tech., 49, 13264-13274, https://doi.org/10.1021/acs.est.5b03392, 2015.

Li, Z., Smith, K. A., and Cappa, C. D.: Influence of relative humidity on the heterogeneous oxidation of secondary 
organic aerosol, Atmos. Chem. Phys., 18, 14585-14608, https://doi.org/10.5194/acp-18-14585-2018, 2018.

Liu, S., Ahlm, L., Day, D. A., Russell, L. M., Zhao, Y. L., Gentner, D. R., Weber, R. J., Goldstein, A. H., Jaoui, M., Offenberg, J. H., Kleindienst, T. E., Rubitschun, C., Surratt, J. D., Sheesley, R. J., and Scheller, S.: Secondary organic aerosol formation from fossil fuel sources contribute majority of summertime organic mass at Bakersfield, J. Geophys. Res.-Atmos., 117, D00V26, https://doi.org/10.1029/2012JD018170, 2012.

Liu, P., Song, M., Zhao, T., Gunthe, S. S., Ham, S., He, Y., Qin, Y. M., Gong, Z., Amorim, J. C., Bertram, A. K., and Martin, S. T.: Resolving the mechanisms of hygroscopic growth and cloud condensation nuclei activity for organic particulate matter, Nat. Commun., 9, 4076, https://doi.org/10.1038/s41467-018-066222, 2018.

Liu, P. F., Li, Y. J., Wang, Y., Gilles, M. K., Zaveri, R. A., Bertram, A. K., and Martin, S. T.: Lability of secondary organic particulate matter, P. Natl. Acad. Sci. USA, 113, 12643-12648, https://doi.org/10.1073/pnas.1603138113, 2016.

Loza, C. L., Coggon, M. M., Nguyen, T. B., Zuend, A., Flagan, R. C., and Seinfeld, J. H.: On the mixing and evaporation of secondary organic aerosol components, Environ. Sci. Technol., 47, 6173-6180, https://doi.org/10.1021/es400979k, 2013.

Maclean, A. M., Butenhoff, C. L., Grayson, J. W., Barsanti, K., Jimenez, J. L., and Bertram, A. K.: Mixing times of organic molecules within secondary organic aerosol particles: a global planetary boundary layer perspective, Atmos. Chem. Phys., 17, 13037-13048, https://doi.org/10.5194/acp-17-130372017, 2017.

Marcolli, C., Luo, B., and Peter, T.: Mixing of the organic aerosol fractions: Liquids as the thermodynamically stable phases, J. Phys. Chem. A, 108, 2216-2224, https://doi.org/10.1021/jp0360801, 2004.

Marcolli, C. and Krieger, U. K.: Phase changes during hygroscopic cycles of mixed organic/inorganic model systems of tropospheric aerosols, J. Phys. Chem. A, 110, 1881-1893, https://doi.org/10.1021/Jp0556759, 2006.

Marshall, F. H., Miles, R. E. H., Song, Y. C., Ohm, P. B., Power, R. M., Reid, J. P., and Dutcher, C. S.: Diffusion and reactivity in ultraviscous aerosol and the correlation with particle viscosity, Chem. Sci., 7, 1298-1308, https://doi.org/10.1039/c5sc03223g, 2016.

Martin, S. T., Andreae, M. O., Althausen, D., Artaxo, P., Baars, H., Borrmann, S., Chen, Q., Farmer, D. K., Guenther, A., Gunthe, S. S., Jimenez, J. L., Karl, T., Longo, K., Manzi, A., Müller, T., Pauliquevis, T., Petters, M. D., Prenni, A. J., Pöschl, U., Rizzo, L. V., Schneider, J., Smith, J. N., Swietlicki, E., Tota, J., Wang, J., Wiedensohler, A., and Zorn, S. R.: An overview of the Amazonian Aerosol Characterization Experiment 2008 (AMAZE-08), Atmos. Chem. Phys., 10, 1141511438, https://doi.org/10.5194/acp-10-11415-2010, 2010.

Massoli, P., Lambe, A. T., Ahern, A. T., Williams, L. R., Ehn, M., Mikkila, J., Canagaratna, M. R., Brune, W. H., Onasch, T. B., Jayne, J. T., Petaja, T., Kulmala, M., Laaksonen, A., Kolb, C. E., Davidovits, P., and Worsnop, D. R.: Relationship between aerosol oxidation level and hygroscopic properties of laboratory generated secondary organic aerosol (SOA) particles, Geophys. Res. Lett., 37, L24801, https://doi.org/10.1029/2010g1045258, 2010 .
Mu, Q., Shiraiwa, M., Octaviani, M., Ma, N., Ding, A. J., Su, H., Lammel, G., Poschl, U., and Cheng, Y. F.: Temperature effect on phase state and reactivity controls atmospheric multiphase chemistry and transport of PAHs, Sci. Adv., 4, eaap7314, https://doi.org/10.1126/sciadv.aap7314, 2018.

Murray, B. J.: Inhibition of ice crystallisation in highly viscous aqueous organic acid droplets, Atmos. Chem. Phys., 8, 54235433, https://doi.org/10.5194/acp-8-5423-2008, 2008.

Murray, B. J. and Bertram, A. K.: Inhibition of solute crystallisation in aqueous $\mathrm{H}^{+}-\mathrm{NH}_{4}^{+}-\mathrm{SO}_{4}^{2-}-\mathrm{H}_{2} \mathrm{O}$ droplets, Phys. Chem. Chem. Phys., 10, 3287-3301, 2008.

Murray, B. J., Wilson, T. W., Dobbie, S., Cui, Z. Q., Al-Jumur, S. M. R. K., Mohler, O., Schnaiter, M., Wagner, R., Benz, S., Niemand, M., Saathoff, H., Ebert, V., Wagner, S., and Karcher, B.: Heterogeneous nucleation of ice particles on glassy aerosols under cirrus conditions, Nat. Geosci., 3, 233-237, https://doi.10.1038/Ngeo817, 2010.

Murray, B. J., Haddrell, A. E., Peppe, S., Davies, J. F., Reid, J. P., O'Sullivan, D., Price, H. C., Kumar, R., Saunders, R. W., Plane, J. M. C., Umo, N. S., and Wilson, T. W.: Glass formation and unusual hygroscopic growth of iodic acid solution droplets with relevance for iodine mediated particle formation in the marine boundary layer, Atmos. Chem. Phys., 12, 8575-8587, https://doi.org/10.5194/acp-12-8575-2012, 2012.

O’Brien, R. E., Wang, B. B., Kelly, S. T., Lundt, N., You, Y., Bertram, A. K., Leone, S. R., Laskin, A., and Gilles, M. K.: Liquid-Liquid Phase Separation in Aerosol Particles: Imaging at the Nanometer Scale, Environ. Sci. Technol., 49, 4995-5002, https://doi.org/10.1021/acs.est.5b00062, 2015.

Odum, J. R., Jungkamp, T. P. W., Griffin, R. J., Flagan, R. C., and Seinfeld, J. H.: The atmospheric aerosol-forming potential of whole gasoline vapor, Science, 276, 96-99, https://doi.10.1126/science.276.5309.96, 1997.

Ovadnevaite, J., Zuend, A., Laaksonen, A., Sanchez, K. J., Roberts, G., Ceburnis, D., Decesari, S., Rinaldi, M., Hodas, N., Facchini, M. C., Seinfeld, J. H., and Dowd, C. O.: Surface tension prevails over solute effect in organic-influenced cloud droplet activation, Nature, 546, 637-641, https://doi.org/10.1038/nature22806, 2017.

Pajunoja, A., Malila, J., Hao, L. Q., Joutsensaari, J., Lehtinen, K. E. J., and Virtanen, A.: Estimating the viscosity range of SOA particles based on their coalescence time, Aerosol Sci. Tech., 48, I-Iv, https://doi.10.1080/02786826.2013.870325, 2014.

Pandis, S. N., Harley, R. A., Cass, G. R., and Seinfeld, J. H.: Secondary organic aerosol formation and transport, Atmos. Environ. A-Gen., 26, 2269-2282, 1992.

Pankow, J. F.: Gas/particle partitioning of neutral and ionizing compounds to single and multi-phase aerosol particles, 1. Unified modeling framework, Atmos. Environ., 37, 3323-3333, https://doi.org/10.1016/S1352-2310(03)00346-7, 2003.

Pant, A., Parsons, M. T., and Bertram, A. K.: Crystallization of aqueous ammonium sulfate particles internally mixed with soot and kaolinite: Crystallization relative humidities and nucleation rates, J. Phys. Chem. A, 110, 8701-8709, https://doi.10.1021/Jp060985s, 2006.

Parsons, M. T., Mak, J., Lipetz, S. R., and Bertram, A. K.: Deliquescence of malonic, succinic, glutaric, and adipic acid particles, J. Geophys. Res.-Atmos., 109, D06212, https://doi.org/10.1029/2003jd004075, 2004. 
Perraud, V., Bruns, E. A., Ezell, M. J., Johnson, S. N., Yu, Y., Alexander, M. L., Zelenyuk, A., Imre, D., Chang, W. L., Dabdub, D., Pankow, J. F., and Finlayson-Pitts, B. J.: Nonequilibrium atmospheric secondary organic aerosol formation and growth, P. Natl. Acad. Sci. USA, 109, 2836-2841, https://doi.10.1073/pnas.1119909109, 2012.

Petters, M. D. and Kreidenweis, S. M.: A single parameter representation of hygroscopic growth and cloud condensation nucleus activity, Atmos. Chem. Phys., 7, 1961-1971, https://doi.org/10.5194/acp-7-1961-2007, 2007.

Petters, M. D., Kreidenweis, S. M., Snider, J. R., Koehler, K. A., Wang, Q., Prenni, A. J., and Demott, P. J.: Cloud droplet activation of polymerized organic aerosol, Tellus B, 58, 196-205, https://doi.org/10.1111/j.1600-0889.2006.00181.x, 2006.

Pöschl, U. and Shiraiwa, M.: Multiphase Chemistry at the Atmosphere-Biosphere Interface Influencing Climate and Public Health in the Anthropocene, Chem. Rev., 115, 4440-4475, https://doi.10.1021/cr500487s, 2015.

Pöschl, U., Martin, S. T., Sinha, B., Chen, Q., Gunthe, S. S., Huffman, J. A., Borrmann, S., Farmer, D. K., Garland, R. M., Helas, G., Jimenez, J. L., King, S. M., Manzi, A., Mikhailov, E., Pauliquevis, T., Petters, M. D., Prenni, A. J., Roldin, P., Rose, D., Schneider, J., Su, H., Zorn, S. R., Artaxo, P., and Andreae, M. O.: Rainforest aerosols as biogenic nuclei of clouds and precipitation in the Amazon, Science, 329, 1513-1516, https://doi.org/10.1126/science.1191056, 2010.

Price, H. C., Mattsson, J., Zhang, Y., Bertram, A. K., Davies, J. F., Grayson, J. W., Martin, S. T., O’Sullivan, D., Reid, J. P., Rickards, A. M. J., and Murray, B. J.: Water diffusion in atmospherically relevant alpha-pinene secondary organic material, Chem. Sci., 6, 4876-4883, https://doi.org/10.1039/c5sc00685f, 2015.

Price, H. C., Mattsson, J., and Murray, B. J.: Sucrose diffusion in aqueous solution, Phys. Chem. Chem. Phys., 18, 19207-19216, https://doi.10.1039/c6cp03238a, 2016.

Rastak, N., Pajunoja, A., Navarro, J. C. A., Ma, J., Song, M., Partridge, D. G., Kirkevag, A., Leong, Y., Hu, W. W., Taylor, N. F., Lambe, A., Cerully, K., Bougiatioti, A., Liu, P., Krejci, R., Petaja, T., Percival, C., Davidovits, P., Worsnop, D. R., Ekman, A. M. L., Nenes, A., Martin, S., Jimenez, J. L., Collins, D. R., Topping, D. O., Bertram, A. K., Zuend, A., Virtanen, A., and Riipinen, I.: Microphysical explanation of the RH-dependent water affinity of biogenic organic aerosol and its importance for climate, Geophys. Res. Lett., 44, 5167-5177, https://doi.org/10.1002/2017gl073056, 2017.

Riipinen, I., Pierce, J. R., Yli-Juuti, T., Nieminen, T., Häkkinen, S., Ehn, M., Junninen, H., Lehtipalo, K., Petäjä, T., Slowik, J., Chang, R., Shantz, N. C., Abbatt, J., Leaitch, W. R., Kerminen, V.-M., Worsnop, D. R., Pandis, S. N., Donahue, N. M., and Kulmala, M.: Organic condensation: a vital link connecting aerosol formation to cloud condensation nuclei (CCN) concentrations, Atmos. Chem. Phys., 11, 3865-3878, https://doi.org/10.5194/acp-11-3865-2011, 2011.

Reid, J. P., Dennis-Smither, B. J., Kwamena, N. O. A., Miles, R. E. H., Hanford, K. L., and Homer, C. J.: The morphology of aerosol particles consisting of hydrophobic and hydrophilic phases: hydrocarbons, alcohols and fatty acids as the hydrophobic component, Phys. Chem. Chem. Phys., 13, 15559-15572, https://doi.org/10.1039/C1cp21510h, 2011.
Reid, J. P., Bertram, A. K., Topping, D. O., Laskin, A., Martin, S. T., Petters, M. D., Pope, F. D., and Rovelli, G.: The viscosity of atmospherically relevant organic particles, Nat. Commun., 9, 956, https://doi.org/10.1038/s41467-018-03027-z, 2018.

Reist, P.: Aerosol science and technology, McGraw-Hill Professional, 2 Edn., New York, NY, USA, 1992.

Renbaum-Wolff, L., Grayson, J. W., Bateman, A. P., Kuwata, M., Sellier, M., Murray, B. J., Shilling, J. E., Martin, S. T., and Bertram, A. K.: Viscosity of alpha-pinene secondary organic material and implications for particle growth and reactivity, P. Natl. Acad. Sci. USA, 110, 8014-8019, https://doi.org/10.1073/pnas.1219548110, 2013.

Renbaum-Wolff, L., Song, M., Marcolli, C., Zhang, Y., Liu, P. F., Grayson, J. W., Geiger, F. M., Martin, S. T., and Bertram, A. K.: Observations and implications of liquid-liquid phase separation at high relative humidities in secondary organic material produced by $\alpha$-pinene ozonolysis without inorganic salts, Atmos. Chem. Phys., 16, 7969-7979, https://doi.org/10.5194/acp16-7969-2016, 2016.

Roach, P. J., Laskin, J., and Laskin, A.: Molecular characterization of organic aerosols using nanospray-desorption/electrospray ionization-mass spectrometry, Anal. Chem., 82, 7979-7986, https://doi.org/10.1021/ac101449p, 2010.

Robinson, E. S., Saleh, R., and Donahue, N. M.: Organic aerosol mixing observed by single-particle mass spectrometry, J. Phys. Chem. A, 117, 13935-13945, https://doi.10.1021/Jp405789t, 2013.

Rothfuss, N. E. and Petters, M. D.: Influence of functional groups on the viscosity of organic aerosol, Environ. Sci. Technol., 51, 271-279, https://doi.org/10.1021/acs.est.6b04478, 2017.

Saukko, E., Lambe, A. T., Massoli, P., Koop, T., Wright, J. P., Croasdale, D. R., Pedernera, D. A., Onasch, T. B., Laaksonen, A., Davidovits, P., Worsnop, D. R., and Virtanen, A.: Humiditydependent phase state of SOA particles from biogenic and anthropogenic precursors, Atmos. Chem. Phys., 12, 7517-7529, https://doi.org/10.5194/acp-12-7517-2012, 2012.

Schauer, J. J., Fraser, M. P., Cass, G. R., and Simoneit, B. R. T.: Source reconciliation of atmospheric gas-phase and particle-phase pollutants during a severe photochemical smog episode, Environ. Sci. Technol., 36, 3806-3814, https://doi.10.1021/Es011458j, 2002a.

Schauer, J. J., Kleeman, M. J., Cass, G. R., and Simoneit, B. R. T.: Measurement of emissions from air pollution sources, 5, C-1-C-32 organic compounds from gasolinepowered motor vehicles, Environ. Sci. Technol., 36, 1169-1180, https://doi.10.1021/Es0108077, 2002b.

Schill, G. P., De Haan, D. O., and Tolbert, M. A.: Heterogeneous ice nucleation on simulated secondary organic aerosol, Environ. Sci. Technol., 48, 1675-1682, 2014.

Seinfeld, J. H. and Pandis, S. N.: Atmospheric chemistry and physics, A Wiley-interscience publication, USA, 2006.

Shiraiwa, M. and Seinfeld, J. H.: Equilibration timescale of atmospheric secondary organic aerosol partitioning, Geophys. Res. Lett., 39, L24801, https://doi.10.1029/2012g1054008, 2012.

Shiraiwa, M., Ammann, M., Koop, T., and Poschl, U.: Gas uptake and chemical aging of semisolid organic aerosol particles, P. Natl. Acad. Sci. USA, 108, 11003-11008, https://doi.10.1073/pnas.1103045108, 2011. 
Shiraiwa, M., Yee, L. D., Schilling, K. A., Loza, C. L., Craven, J. S., Zuend, A., Ziemann, P. J., and Seinfeld, J. H.: Size distribution dynamics reveal particle-phase chemistry in organic aerosol formation, P. Natl. Acad. Sci. USA, 110, 11746-11750, https://doi.10.1073/pnas.1307501110, 2013a.

Shiraiwa, M., Zuend, A., Bertram, A. K., and Seinfeld, J. H.: Gas particle partitioning of atmospheric aerosols: interplay of physical state, non-ideal mixing and morphology, Phys. Chem. Chem. Phys., 15, 11441-11453, https://doi.org/10.1039/C3cp51595h, 2013b.

Shiraiwa, M., Li, Y., Tsimpidi, A. P., Karydis, V. A., Berkemeier, T., Pandis, S. N., Lelieveld, J., Koop, T., and Poschl, U.: Global distribution of particle phase state in atmospheric secondary organic aerosols, Nat. Commun., 8, 15002, https://doi.10.1038/ncomms15002, 2017.

Shrivastava, M., Cappa, C. D., Fan, J. W., Goldstein, A. H., Guenther, A. B., Jimenez, J. L., Kuang, C., Laskin, A., Martin, S. T., Ng, N. L., Petaja, T., Pierce, J. R., Rasch, P. J., Roldin, P., Seinfeld, J. H., Shilling, J., Smith, J. N., Thornton, J. A., Volkamer, R., Wang, J., Worsnop, D. R., Zaveri, R. A., Zelenyuk, A., and Zhang, Q.: Recent advances in understanding secondary organic aerosol: Implications for global climate forcing, Rev. Geophys., 55, 509-559, https://doi.org/10.1002/2016rg000540, 2017a.

Shrivastava, M., Lou, S., Zelenyuk, A., Easter, R. C., Corley, R. A., Thrall, B. D., Rasch, P. J., Fast, J. D., Simonich, S. L. M., Shen, H. Z., and Tao, S.: Global long-range transport and lung cancer risk from polycyclic aromatic hydrocarbons shielded by coatings of organic aerosol, P. Natl. Acad. Sci. USA, 114, 1246-1251, https://doi.org/10.1073/pnas.1618475114, 2017b.

Solomon, S.: Climate change 2007-the physical science basis: Working group I contribution to the fourth assessment report of the IPCC, Cambridge University Press, Cambridge, 2007.

Song, M., Marcolli, C., Krieger, U. K., Zuend, A., and Peter, T.: Liquid-liquid phase separation and morphology of internally mixed dicarboxylic acids/ammonium sulfate/water particles, Atmos. Chem. Phys., 12, 2691-2712, https://doi.org/10.5194/acp12-2691-2012, 2012a.

Song, M., Marcolli, C., Krieger, U. K., Zuend, A., and Peter, T.: Liquid-liquid phase separation in aerosol particles: Dependence on O : C, organic functionalities, and compositional complexity, Geophys. Res. Lett., 39, L19801, https://doi.org/10.1029/2012gl052807, 2012b.

Song, M., Liu, P. F., Hanna, S. J., Li, Y. J., Martin, S. T., and Bertram, A. K.: Relative humidity-dependent viscosities of isoprene-derived secondary organic material and atmospheric implications for isoprene-dominant forests, Atmos. Chem. Phys., 15, 5145-5159, https://doi.org/10.5194/acp-155145-2015, 2015.

Song, M., Liu, P. F., Hanna, S. J., Zaveri, R. A., Potter, K., You, Y., Martin, S. T., and Bertram, A. K.: Relative humiditydependent viscosity of secondary organic material from toluene photo-oxidation and possible implications for organic particulate matter over megacities, Atmos. Chem. Phys., 16, 8817-8830, https://doi.org/10.5194/acp-16-8817-2016, 2016.

Song, M., Liu, P., Martin, S. T., and Bertram, A. K.: Liquid-liquid phase separation in particles containing secondary organic material free of inorganic salts, Atmos. Chem. Phys., 17, 1126111271, https://doi.org/10.5194/acp-17-11261-2017, 2017.
Song, M., Ham, S., Andrews, R. J., You, Y., and Bertram, A. K.: Liquid-liquid phase separation in organic particles containing one and two organic species: importance of the average O:C, Atmos. Chem. Phys., 18, 12075-12084, https://doi.org/10.5194/acp-18-12075-2018, 2018.

Song, M. J., Marcolli, C., Krieger, U. K., Lienhard, D. M., and Peter, T.: Morphologies of mixed organic/inorganic/aqueous aerosol droplets, Faraday Discuss., 165, 289-316, https://doi.10.1039/C3fd00049d, 2013.

Song, Y. C., Haddrell, A. E., Bzdek, B. R., Reid, J. P., Barman, T., Topping, D. O., Percival, C., and Cai, C.: Measurements and predictions of binary component aerosol particle viscosity, J. Phys. Chem. A, 120, 8123-8137, doi10.1021/acs.jpca.6b07835, 2016.

Steimer, S. S., Lampimäki, M., Coz, E., Grzinic, G., and Ammann, M.: The influence of physical state on shikimic acid ozonolysis: a case for in situ microspectroscopy, Atmos. Chem. Phys., 14, 10761-10772, https://doi.org/10.5194/acp-14-107612014, 2014.

Ullmann, D. A., Hinks, M. L., Maclean, A. M., Butenhoff, C. L., Grayson, J. W., Barsanti, K., Jimenez, J. L., Nizkorodov, S. A., Kamal, S., and Bertram, A. K.: Viscosities, diffusion coefficients, and mixing times of intrinsic fluorescent organic molecules in brown limonene secondary organic aerosol and tests of the Stokes-Einstein equation, Atmos. Chem. Phys., 19, 14911503, https://doi.org/10.5194/acp-19-1491-2019, 2019.

Veghte, D. P., Altaf, M. B., and Freedman, M. A.: Size dependence of the structure of organic aerosol, J. Am. Chem. Soc., 135, 16046-16049, https://doi.org/10.1021/ja408903g, 2013.

Velasco, E., Lamb, B., Westberg, H., Allwine, E., Sosa, G., ArriagaColina, J. L., Jobson, B. T., Alexander, M. L., Prazeller, P., Knighton, W. B., Rogers, T. M., Grutter, M., Herndon, S. C., Kolb, C. E., Zavala, M., de Foy, B., Volkamer, R., Molina, L. T., and Molina, M. J.: Distribution, magnitudes, reactivities, ratios and diurnal patterns of volatile organic compounds in the Valley of Mexico during the MCMA 2002 \& 2003 field campaigns, Atmos. Chem. Phys., 7, 329-353, https://doi.org/10.5194/acp-7329-2007, 2007.

Velasco, E., Pressley, S., Grivicke, R., Allwine, E., Coons, T., Foster, W., Jobson, B. T., Westberg, H., Ramos, R., Hernández, F., Molina, L. T., and Lamb, B.: Eddy covariance flux measurements of pollutant gases in urban Mexico City, Atmos. Chem. Phys., 9, 7325-7342, https://doi.org/10.5194/acp-9-7325-2009, 2009.

Virtanen, A., Joutsensaari, J., Koop, T., Kannosto, J., Yli-Pirila, P., Leskinen, J., Makela, J. M., Holopainen, J. K., Poschl, U., Kulmala, M., Worsnop, D. R., and Laaksonen, A.: An amorphous solid state of biogenic secondary organic aerosol particles, Nature, 467, 824-827, https://doi.org/10.1038/nature09455, 2010.

Vutukuru, S., Griffin, R. J., and Dabdub, D.: Simulation and analysis of secondary organic aerosol dynamics in the South Coast Air Basin of California, J. Geophys. Res.-Atmos., 111, D10S12, https://doi.org/10.1029/2005jd006139, 2006.

Wang, B. B., Lambe, A. T., Massoli, P., Onasch, T. B., Davidovits, P., Worsnop, D. R., and Knopf, D. A.: The deposition ice nucleation and immersion freezing potential of amorphous secondary organic aerosol: Pathways for ice and mixedphase cloud formation, J. Geophys. Res.-Atmos., 117, D16209, https://doi.10.1029/2012jd018063, 2012.

Wang, B. B., O’Brien, R. E., Kelly, S. T., Shilling, J. E., Moffet, R. C., Gilles, M. K., and Laskin, A.: Reactivity of liquid and 
semisolid secondary organic carbon with chloride and nitrate in atmospheric aerosols, J. Phys. Chem. A, 119, 4498-4508, 2015.

Wang, L. N., Cai, C., and Zhang, Y. H.: Kinetically determined hygroscopicity and efflorescence of sucrose-ammonium sulfate aerosol droplets under lower RH, J. Phys. Chem. B, 121, 85518557, https://doi.org/10.1021/acs.jpcb.7b05551, 2017.

Wilson, J., Imre, D., Beranek, J., Shrivastava, M., and Zelenyuk, A.: Evaporation Kinetics of Laboratory-Generated Secondary Organic Aerosols at Elevated Relative Humidity, Environ. Sci. Technol., 49, 243-249, https://doi.org/10.1021/es505331d, 2015.

Wilson, T. W., Murray, B. J., Wagner, R., Möhler, O., Saathoff, H., Schnaiter, M., Skrotzki, J., Price, H. C., Malkin, T. L., Dobbie, S., and Al-Jumur, S. M. R. K.: Glassy aerosols with a range of compositions nucleate ice heterogeneously at cirrus temperatures, Atmos. Chem. Phys., 12, 8611-8632, https://doi.org/10.5194/acp12-8611-2012, 2012.

Ye, Q., Robinson, E. S., Ding, X., Ye, P. L., Sullivan, R. C., and Donahue, N. M.: Mixing of secondary organic aerosols versus relative humidity, P. Natl. Acad. Sci. USA, 113, 12649-12654, https://doi.org/10.1073/pnas.1604536113, 2016.

Ye, Q., Upshur, M. A., Robinson, E. S., Geiger, F. M., Sullivan, R. C., Thomson, R. J., and Donahue, N. M.: Following particle-particle mixing in atmospheric secondary organic aerosols by using isotopically labeled terpenes, Chem.-US, 4, 318-333, https://doi.org/10.1016/j.chempr.2017.12.008, 2018.

Yli-Juuti, T., Pajunoja, A., Tikkanen, O. P., Buchholz, A., Faiola, C., Vaisanen, O., Hao, L. Q., Kari, E., Perakyla, O., Garmash, O., Shiraiwa, M., Ehn, M., Lehtinen, K., and Virtanen, A.: Factors controlling the evaporation of secondary organic aerosol from alpha-pinene ozonolysis, Geophys. Res. Lett., 44, 2562-2570, https://doi.org/10.1002/2016gl072364, 2017

You, Y., Smith, M. L., Song, M. J., Martin, S. T., and Bertram, A. K.: Liquid-liquid phase separation in atmospherically relevant particles consisting of organic species and inorganic salts, Int. Rev. Phys. Chem., 33, 43-77, https://doi.org/10.1080/0144235X.2014.890786, 2014.

Zaveri, R. A., Easter, R. C., Shilling, J. E., and Seinfeld, J. H.: Modeling kinetic partitioning of secondary organic aerosol and size distribution dynamics: representing effects of volatility, phase state, and particle-phase reaction, Atmos. Chem. Phys., 14, 5153-5181, https://doi.org/10.5194/acp-14-5153-2014, 2014.

Zaveri, R. A., Shilling, J. E., Zelenyuk, A., Liu, J. M., Bell, D. M., D’Ambro, E. L., Gaston, C., Thornton, J. A., Laskin, A., Lin, P., Wilson, J., Easter, R. C., Wang, J., Bertram, A. K., Martin, S. T., Seinfeld, J. H., and Worsnop, D. R.: Growth kinetics and size distribution dynamics of viscous secondary organic aerosol, Environ. Sci. Technol., 52, 1191-1199, https://doi.org/10.1021/acs.est.7b04623, 2018.
Zelenyuk, A., Imre, D., Beranek, J., Abramson, E., Wilson, J., and Shrivastava, M.: Synergy between secondary organic aerosols and long-range transport of polycyclic aromatic hydrocarbons, Environ. Sci. Technol., 46, 12459-12466, https://doi.10.1021/Es302743z, 2012.

Zhang, Q., Jimenez, J. L., Canagaratna, M. R., Allan, J. D., Coe, H., Ulbrich, I., Alfarra, M. R., Takami, A., Middlebrook, A. M., Sun, Y. L., Dzepina, K., Dunlea, E., Docherty, K., DeCarlo, P. F., Salcedo, D., Onasch, T., Jayne, J. T., Miyoshi, T., Shimono, A., Hatakeyama, S., Takegawa, N., Kondo, Y., Schneider, J., Drewnick, F., Borrmann, S., Weimer, S., Demerjian, K., Williams, P., Bower, K., Bahreini, R., Cottrell, L., Griffin, R. J., Rautiainen, J., Sun, J. Y., Zhang, Y. M., and Worsnop, D. R.: Ubiquity and dominance of oxygenated species in organic aerosols in anthropogenically-influenced Northern Hemisphere midlatitudes, Geophys. Res. Lett., 34, L13801, https://doi.10.1029/2007g1029979, 2007.

Zhang, Y., Sanchez, M. S., Douet, C., Wang, Y., Bateman, A. P., Gong, Z., Kuwata, M., Renbaum-Wolff, L., Sato, B. B., Liu, P. F., Bertram, A. K., Geiger, F. M., and Martin, S. T.: Changing shapes and implied viscosities of suspended submicron particles, Atmos. Chem. Phys., 15, 7819-7829, https://doi.org/10.5194/acp15-7819-2015, 2015.

Zhang, Y., Chen, Y. Z., Lambe, A. T., Olson, N. E., Lei, Z. Y., Craig, R. L., Zhang, Z. F., Gold, A., Onasch, T. B., Jayne, J. T., Worsnop, D. R., Gaston, C. J., Thornton, J. A., Vizuete, W., Ault, A. P., and Surratt, J. D.: Effect of the aerosol-phase state on secondary organic aerosol formation from the reactive uptake of isoprene-derived epoxydiols (IEPDX), Environ. Sci. Tech. Let., 5, 167-174, https://doi.org/10.1021/acs.estlett.8b00044, 2018.

Zhou, S. M., Shiraiwa, M., McWhinney, R. D., Poschl, U., and Abbatt, J. P. D.: Kinetic limitations in gas-particle reactions arising from slow diffusion in secondary organic aerosol, Faraday Discuss., 165, 391-406, https://doi.10.1039/C3fd00030c, 2013.

Zobrist, B., Marcolli, C., Pedernera, D. A., and Koop, T.: Do atmospheric aerosols form glasses?, Atmos. Chem. Phys., 8, 52215244, https://doi.org/10.5194/acp-8-5221-2008, 2008.

Zuend, A. and Seinfeld, J. H.: Modeling the gas-particle partitioning of secondary organic aerosol: the importance of liquidliquid phase separation, Atmos. Chem. Phys., 12, 3857-3882, https://doi.org/10.5194/acp-12-3857-2012, 2012.

Zuend, A., Marcolli, C., Peter, T., and Seinfeld, J. H.: Computation of liquid-liquid equilibria and phase stabilities: implications for RH-dependent gas/particle partitioning of organicinorganic aerosols, Atmos. Chem. Phys., 10, 7795-7820, https://doi.org/10.5194/acp-10-7795-2010, 2010. 